\title{
Novel concepts on the role of prostaglandins on luteal maintenance and maternal recognition and establishment of pregnancy in ruminants ${ }^{1}$
}

\author{
Joe A. Arosh, ${ }^{2}$ Sakhila K. Banu, ${ }^{*}$ and John A. McCracken† \\ ${ }^{*}$ Reproductive Endocrinology and Cell Signaling Laboratory, Department of Veterinary Integrative Biosciences, \\ College of Veterinary Medicine and Biomedical Sciences, Texas A\&M University, College Station 77483 \\ †Department of Animal Science, University of Connecticut, Storrs 06269
}

\begin{abstract}
In ruminants, the corpus luteum (CL) of early pregnancy is resistant to luteolysis. Prostaglandin (PG) $\mathrm{E}_{2}$ is considered a luteoprotective mediator. Early studies indicate that during maternal recognition of pregnancy (MRP) in ruminants, a factor(s) from the conceptus or gravid uterus reaches the ovary locally through the utero-ovarian plexus (UOP) and protects the CL from luteolysis. The local nature of the embryonic antiluteolytic or luteoprotective effect precludes any direct effect of a protein transported or acting between the gravid uterus and CL in ruminants. During MRP, interferon tau (IFNT) secreted by the trophoblast of the conceptus inhibits endometrial pulsatile release of $\mathrm{PGF}_{2 \alpha}$ and increases endometrial $\mathrm{PGE}_{2}$. Our recent studies indicate that (1) luteal PG biosynthesis is selectively directed toward $\mathrm{PGF}_{2 \alpha}$ at the time of luteolysis and toward $\mathrm{PGE}_{2}$ at the time of establishment of pregnancy (ESP); (2) the ability of the CL of early pregnancy to resist luteolysis is likely due to increased intraluteal biosynthesis and signaling of $\mathrm{PGE}_{2}$; and (3) endometrial $\mathrm{PGE}_{2}$ is transported from the uterus to the CL through the UOP vascular route during ESP in sheep. Intrauterine coadministration of IFNT and prostaglandin $\mathrm{E}_{2}$ synthase 1 (PGES-1) inhibitor reestablishes endometrial $\mathrm{PGF}_{2 \alpha}$ pulses and regresses the CL. In contrast, intrauterine co-administration of IFNT and PGES-1 inhibitor along with intraovarian administration of $\mathrm{PGE}_{2}$ rescues the CL. Together, the accumulating information provides compelling evidence that $\mathrm{PGE}_{2}$ produced by the CL in response to endometrial $\mathrm{PGE}_{2}$ induced by pregnancy may counteract the luteolytic effect of $\mathrm{PGF}_{2 \alpha}$ as an

\footnotetext{
Received August 31, 2015.

Accepted February 3, 2016.

${ }^{1}$ Presented as part of the Progesterone as an Endocrine Regulator

${ }^{2}$ Corresponding author: jarosh@cvm.tamu.edu
} symposium at the ADSA-ASAS Joint Annual Meeting, Orlando, Florida, July 2015.
\end{abstract}

additional luteoprotective mechanism during MRP or ESP in ruminants. Targeting $\mathrm{PGE}_{2}$ biosynthesis and signaling selectively in the endometrium or CL may provide luteoprotective therapy to improve reproductive efficiency in ruminants.

Key words: prostaglandin, corpus luteum, endometrium, establishment of pregnancy

\section{PROSTAGLANDINS}

Prostaglandins (PG), thromboxanes (TX), and leukotrienes (LT) are classified as eicosanoids (from the Greek eicosa, meaning 20), which describe the broad group of compounds derived from $\mathrm{C}_{20}$ fatty acids. Prostaglandins are 20-carbon unsaturated hydroxyl fatty acids with a cyclopentane ring. Arachidonic acid, an essential fatty acid, is the principal precursor for PG. In mammals, $\mathrm{PG}$ play important roles in several physiological and pathological processes (McCracken, 2005).

\section{Biosynthesis of PG}

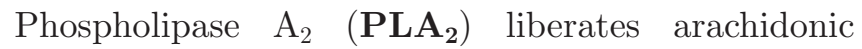
acid from membrane phospholipids. Cyclooxygenases (COX) 1 and 2 convert arachidonic acid into $\mathrm{PGH}_{2}$, the common intermediate metabolite for biosynthesis of various $\mathrm{PG}$, and $\mathrm{PGH}_{2}$ is then converted into selective $\mathrm{PG}$ including $\mathrm{PGF}_{2 \alpha}, \mathrm{PGE}_{2}, \mathrm{PGD}_{2}, \mathrm{PGI}_{2}$, and $\mathrm{TXA}_{2}$ by specific synthases (Smith and Dewitt, 1996; Kudo and Murakami, 1999; Thorén and Jakobsson, 2000; Smith and Song, 2002; Thorén et al., 2003). Prostaglandin F synthase (PGFS, such as AKR1B1, AKR1C1, AKR1C2, and AKR1C3) and prostaglandin E synthase (PGES-1, -2, and -3) convert $\mathrm{PGH}_{2}$ into $\mathrm{PGF}_{2 \alpha}$ and $\mathrm{PGE}_{2}$, respectively. Catabolism of $\mathrm{PG}$ is governed by prostaglandin 15-dehydrogenase (PGDH), which catabolizes $\mathrm{PGF}_{2 \alpha}$ into inactive 15-keto-13,14-dihydro $\mathrm{PGF}_{2 \alpha}$ (PGFM), and catabolizes $\mathrm{PGE}_{2}$ into inactive 13,14-dihydro-15-keto $\mathrm{PGE}_{2}$ (PGEM; Tai et al., 2002). An overview on PG metabolic pathways is depicted in Figure 1. 


\section{Prostaglandin Metabolic and Signaling Pathways}
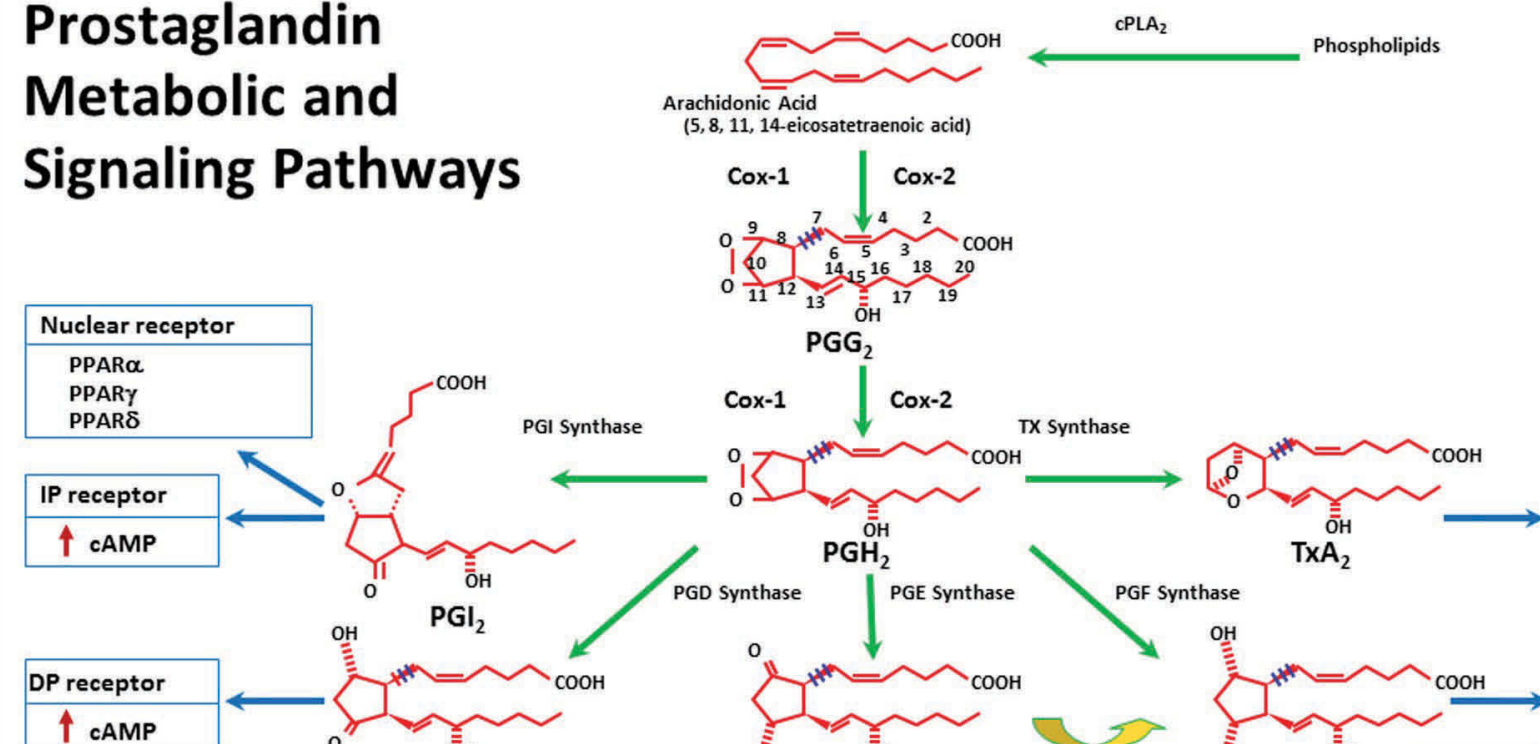

TP receptor

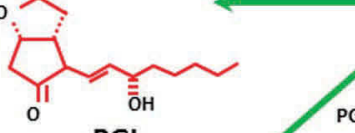

$\mathrm{PGI}_{2}$ PGE Synthase
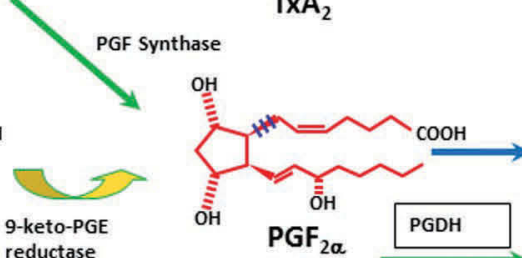

$\mathrm{Ca}^{2+}+\mathrm{IP}_{3}$

\begin{tabular}{|c|}
\hline Relaxant Receptors \\
\hline T cAMP \\
\hline
\end{tabular}

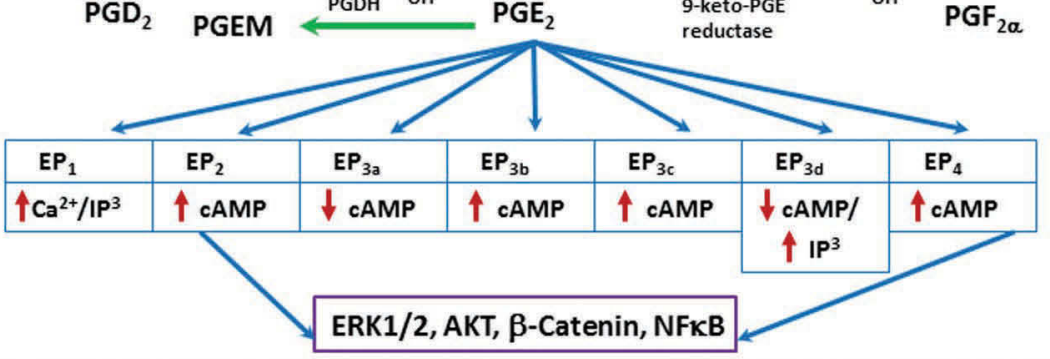

Constrictor Receptors

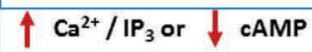

Figure 1. Overview on biosynthesis and signaling of prostaglandins, which is developed based on published information (Kanai et al., 1995 Smith and Dewitt, 1996; Kudo and Murakami, 1999; Narumiya et al., 1999; Narumiya and FitzGerald, 2001; Smith and Song, 2002; Tai et al., 2002; Thorén and Jakobsson, 2000; Thorén et al., 2003; Castellone et al., 2005; Buchanan et al., 2006; Cha and DuBois, 2007). PG = prostaglandin; $\mathrm{PPAR}=$ peroxisome proliferator-activated receptor; $\mathrm{COX}=$ cyclooxygenase; $\mathrm{DP}=$ prostaglandin $\mathrm{D}_{2}$ receptor; $\mathrm{EP}=$ prostaglandin $\mathrm{E}_{2}$ receptor; $\mathrm{FP}=\mathrm{PGF}_{20}$ receptor; $\mathrm{ERK} 1 / 2=$ extracellular signal-regulated protein kinases 1 and $2 ; \mathrm{AKT}=$ protein kinase $\mathrm{B}$; $\mathrm{NF}$-kB $=$ nuclear factor kappa $\mathrm{B} ; \mathrm{IP}_{3}=$ inositol trisphosphate; $\mathrm{PGDH}=$ prostaglandin 15 -dehydrogenase; $\mathrm{PGEM}=$ inactive 13,14 -dihydro-15-keto $\mathrm{PGE}$; $P$ GFM = inactive 15-keto-13,14-dihydro $\mathrm{PGF}_{2 \alpha}$; $\mathrm{TX}=$ thromboxane. Color version available online.

\section{Transport of PG}

Transport of PG through plasma membranes is poorly understood, with proposed mechanisms including from simple diffusion, passive transport, active transport, counter current exchange, and carrier-mediated transport. The PG are organic anions and cross cellular membranes by simple diffusion; however, the estimated flow rate is too low and insufficient to bring forth their biological effects. In the pulmonary circulation, $\mathrm{PGE}_{2}$ and $\mathrm{PGF}_{2 \alpha}$ are catabolized rapidly in one passage through the lungs. Therefore, a carrier-mediated transport mechanism is required for cellular transport of PG. Prostaglandin transporter (PGT) is a member of the 12-transmembrane solute carrier organic anion transporter (OATP) 2A1 (SLCO2A1) family (Schuster, 1998, 2002); PGT transports $\mathrm{PGF}_{2 \alpha}, \mathrm{PGE}_{2}, \mathrm{PGD}_{2}$, and
$\mathrm{TxA}_{2}$ in a competitive manner, with different affinities for each PG. We and others using pharmacological and genomic approaches have shown that inhibition of PGT prevents PGT-mediated transport of PG in various cell types (Kanai et al., 1995; Chan et al., 1998; Banu et al., 2003, 2008).

\section{Signaling of $P G$}

Prostaglandin $\mathrm{F}_{2 \alpha}$ and $\mathrm{PGE}_{2}$ elicit their autocrine, paracrine, or endocrine biological actions through FP and EP (EP1, EP2, EP3, and EP4) receptors, respectively, by activating multiple signaling cascades (Coleman et al., 1994; Narumiya et al., 1999; Narumiya and FitzGerald, 2001). The FP and EP1 receptors are coupled to the Gq protein and activate phospholipase $\mathrm{C}$, which generates 2 second messengers: inositol tri- 
sphosphate $\left(\mathbf{I P}_{3}\right)$ mobilizes intracellular calcium $\left(\mathrm{Ca}^{2+}\right)$ and diacylglycerol activates protein kinase $\mathrm{C}(\mathbf{P K C})$. The EP2 and EP4 receptors are coupled to Gs protein and activate adenylyl cyclase and generate cyclic (c) AMP, which in turn activates protein kinase A (PKA). The EP3 receptor is coupled to Gq, Gs, and Gi proteins and is associated with inhibition or induction of cAMP. Activation of EP3 receptor also increases mobilization of $\mathrm{Ca}^{2+}$ and $\mathrm{IP}_{3}$ (Narumiya et al., 1999). The EP (Castellone et al., 2005; Buchanan et al., 2006; Cha and DuBois, 2007; Banu et al., 2009) and FP (Sales et al., 2005, 2007; Guo et al., 2012) receptors cross-talk with multiple intracellular pathways. An overview on PG signaling pathways is depicted in Figure 1.

\section{Requirement for Pulsatile Release of Endometrial PGF $_{2 \alpha}$ During Luteolysis in Ruminants}

Luteolysis is a neuroendocrine-mediated event. Functional luteolysis denotes the decline in progesterone (P4) production by the corpus luteum (CL). Structural luteolysis denotes the physical involution and regression of luteal tissues. The relationship between functional and structural luteolysis has not been clearly defined; however, functional luteolysis appears to precede structural luteolysis (McCracken et al., 1999; Niswender et al., 2000). In ruminants, endometrial $\mathrm{PGF}_{2 \alpha}$ is the luteolytic hormone that causes functional and structural luteolysis through multiple mechanisms (McCracken et al., 1999; Niswender et al., 2000). At the time of luteolysis, $\mathrm{PGF}_{2 \alpha}$ is released from the endometrium in a pulsatile pattern. Development of the luteolytic mechanism is largely under the regulation of P4, estradiol, and oxytocin (Hooper et al., 1986; McCracken et al., 1999). In sheep, continuous exposure of endometrium to $\mathrm{P} 4$ for 8 to $10 \mathrm{~d}$ downregulates expression of nuclear $\mathrm{P} 4$ receptor (PGR) in luminal epithelial ( $\mathbf{L E})$ cells between $\mathrm{d} 11$ and 13, thereby allowing a rapid increase in expression of estrogen receptor $\alpha$ (ESR1) after d 13, followed by an increase in expression of oxytocin receptor (OXTR) after d 14 of the estrous cycle (McCracken et al., 1999; Spencer et al., 2004, 2007). Pulsatile release of oxytocin from the posterior pituitary after d 13 to 14 of the estrous cycle acts on endometrial OXTR and induces the release of luteolytic pulses of $\mathrm{PGF}_{2 \alpha}$ from the endometrial LE cells between d 14 and 16 of the estrous cycle. Luteal oxytocin acts as a supplemental source of oxytocin to boost the oxytocin pulse from the posterior pituitary and amplify the luteolytic pulses of $\mathrm{PGF}_{2 \alpha}$ from the endometrium during luteolysis (McCracken et al., 1995, 1999). Five endometrial $\mathrm{PGF}_{2 \alpha}$ pulses of 1-h duration over a period of $48 \mathrm{~h}$ at 8 -h intervals are required to consistently cause complete CL regression in sheep. Reducing the duration of pulses of $\mathrm{PGF}_{2 \alpha}$ from 1 to $0.5 \mathrm{~h}$ failed to cause luteolysis, even after six 0.5-h pulses (McCracken et al., 2012). Endometrial $\mathrm{PGF}_{2 \alpha}$ pulses are secreted into the uterine vein, which joins the ovarian vein to form the utero-ovarian vein. These luteolytic $\mathrm{PGF}_{2 \alpha}$ pulses are transported from the utero-ovarian vein into the ovarian artery locally through a unique vascular structure called the uteroovarian plexus (UOP; McCracken et al., 1972, 2012). Local transport of $\mathrm{PGF}_{2 \alpha}$ through the UOP is obligatory for regression of the CL in sheep, because $99 \%$ of $\mathrm{PGF}_{2 \alpha}$ secreted by the endometrium is catabolized into its inactive stable metabolite PGFM by PGDH after a single systemic passage through the lungs (Davis et al., 1980). The reviews by McCracken et al. (1999) and Niswender et al. (2000) provide more details on functional and structural luteolysis in ruminants.

\section{Requirement for Luteal Biosynthesis of $P G F_{2 \alpha}$ During Luteolysis in Ruminants}

Administration of $\mathrm{PGF}_{2 \alpha}$ during the mid-luteal phase of the estrous cycle increases luteal $\mathrm{PGF}_{2 \alpha}$ production which is inhibited by pretreatment with indomethacin (COX-1/2 inhibitor), as measured in CL explant cultures (Rexroad and Guthrie, 1979). Systemic blockade with indomethacin inhibits endometrial and luteal $\mathrm{PGF}_{2 \alpha}$ biosynthesis. Importantly, indomethacin blockade does not inhibit the decrease in P4 levels (functional luteolysis) in response to luteolytic $\mathrm{PGF}_{2 \alpha}$ (Guthrie, 1979). Both Rexroad and Guthrie (1979) and Guthrie (1979) suggest that luteal synthesis of $\mathrm{PGF}_{2 \alpha}$ is not required for functional luteolysis; however, the effect of indomethacin treatment on structural luteolysis (size and weight of the CL) was not measured. Administration of luteolytic $\mathrm{PGF}_{2 \alpha}$ in vivo and treatment of luteal cells with $\mathrm{PGF}_{2 \alpha}$ in vitro induce expression of COX-2 mRNA in luteal tissues and cells in sheep (Tsai and Wiltbank, 1997, 1998; Anderson et al., 2001). These findings strengthen the view that luteal synthesis of $\mathrm{PGF}_{2 \alpha}$ is likely to be an important part of a positive feedback loop between the uterus and the CL during the process of luteolysis. In support of this view, a recent study (Niswender et al., 2007) indicates that indomethacin, in the form of a polymerized gel implanted surgically into the ovine CL at mid cycle, does not inhibit the effects of luteolytic $\mathrm{PGF}_{2 \alpha}$ on decreasing circulating P4 levels (functional luteolysis); however, it does inhibit the effects of luteolytic $\mathrm{PGF}_{2 \alpha}$ on size and weight of the CL and maintains the structure (structural luteolysis). These studies together suggest that endometrial $\mathrm{PGF}_{2 \alpha}$ causes functional luteolysis, whereas luteal $\mathrm{PGF}_{2 \alpha}$ may cause structural luteolysis (Sawyer et al., 1990; Juen- 
gel et al., 1993; Zheng et al., 1994; Niswender et al., 2007; Sugino and Okuda, 2007). However, the absolute requirement for luteal $\mathrm{PGF}_{2 \alpha}$ in functional versus structural luteolysis has yet to be established.

\section{Molecular Control of Luteal P4 Biosynthesis in Ruminants}

The CL has large steroidogenic cells (LLC) and small steroidogenic cells (SLC) besides fibroblasts, immune cells, and endothelial cells. The LLC and SLC are thought to be derived from the granulosa and theca cells, respectively (McCracken et al., 1999; Niswender et al., 2000). Luteal steroidogenesis depends on transport of cholesterol. The steroidogenic acute regulatory protein (StAR) protein transports the cholesterol from the outer to the inner mitochondrial membrane. The cholesterol side-chain cleavage enzyme (P-450scc), located on the inner membrane of mitochondria, converts cholesterol to pregnenolone. 3 3 -Hydroxysteroid dehydrogenase ( $3 \beta$-HSD) enzyme converts pregnenolone to P4 (Niswender, 2002). The StAR protein is expressed in LLC and SLC and regulated by cAMP/PKA and ERK1/2 pathways (Wiltbank et al., 1993; Manna et al., 2009). The SLC secrete basal levels of P4 but respond to $\mathrm{LH} / \mathrm{cAMP} / \mathrm{PKA}$ with an increase in $\mathrm{P} 4$ production (McCracken et al., 1999; Niswender et al., 2000). The LLC secrete high levels of basal P4 and do not respond to LH stimulation. The driving factor for the constitutive cAMP/PKA activation and $\mathrm{P} 4$ production by the LLC is largely unknown. Prostaglandin $\mathrm{E}_{2} / \mathrm{EP} 2 / \mathrm{EP} 4$ signaling activates cAMP/PKA pathways in most cell types under physiological conditions (Narumiya et al., 1999). It is possible that luteal $\mathrm{PGE}_{2} / \mathrm{EP} 2 / \mathrm{EP} 4$ signaling could drive the constitutive activation of cAMP/ PKA in LLC, but this notion needs be examined in functional studies. The review by Niswender (2002) provides more details on molecular control of luteal P4 biosynthesis in ruminants.

\section{Maternal Recognition and Establishment of Pregnancy in Ruminants}

During the maternal recognition (MRP) and establishment of pregnancy (ESP) in ruminants, interferon tau (IFNT), a type 1 interferon, is secreted by the mononuclear cells of trophectoderm of the conceptus (Imakawa et al., 1987). Interferon tau acts on LE cells in a paracrine manner and suppresses transcription of both ESR1 and OXTR genes in sheep (Spencer et al., 2004, 2007) and cows (Mann et al., 1999; Robinson et al., 2008), and thereby inhibits oxytocin-induced pulsatile release of luteolytic $\mathrm{PGF}_{2 \alpha}$ by the endome- trium. Interferon tau signaling is mediated through a cell surface receptor that is composed of 2 subunits, IFNAR1 and IFNAR2. The well-characterized downstream signal transduction pathways of type I IFN is activation of tyrosine kinase 2 (TYK2) and Janus kinase 1 (JAK1) and signal transducer and activator of transcription (STAT), collectively known as the JAK/STAT pathways (Stewart et al., 2001; Wang and Roberts, 2004). Activation of JAK/STAT in turn regulates phosphorylation and activation of STAT and IFNstimulated genes (ISG). Phosphorylated STAT1 and STAT2 (heterodimers) together with IFN regulatory factor-9 (IRF-9) form IFN-stimulated gene factor 3 (ISGF3) transcriptional complex that translocates to the nucleus and binds with IFN-stimulated response elements (ISRE) to initiate transcription of specific ISG. Interestingly, IFNAR1 and IFNAR2 genes are expressed (Rosenfeld et al., 2002) but STAT1, STAT2, and IRF-9 genes are not expressed in endometrial LE cells at the time of MRP in sheep (Choi et al., 2001; Spencer et al., 2007). On the other hand, IFNT-stimulated genes are expressed in LE cells (Song et al., 2006). This suggests that IFNT can activate STAT-independent cell signaling pathways in endometrial LE cells at the time of MRP/ESP (Spencer et al., 2007).

\section{Novel IFNT Downstream Signaling During MRP in Ruminants}

In deciphering novel IFNT signaling, we have recently identified that IFNT activates JAK-SRC-EGFR-RASRAF-ERK1/2-EGR-1 signaling pathways in the ovine endometrial luminal epithelial (oLE) cells in vitro (Banu et al., 2010). Using oLE cell cultures, immunoprecipitation, and ERK1/2 short interfering (si)RNA approaches, we have shown that IFNT phosphorylates PGT protein at tyrosine and threonine residues and concomitantly dephosphorylates PGT protein at serine residues, and thus inhibits PGT-mediated release of endometrial $\mathrm{PGF}_{2 \alpha}$ through ERK1/2 pathways. These findings indicate that interactions between ERK1/2 and PGT are the important cell-signaling cascades required to inhibit $\mathrm{PGT}$-mediated pulsatile release of $\mathrm{PGF}_{2 \alpha}$ from the ovine endometrium (Banu et al., 2010; Lee et al., 2013). Next, we analyzed expression, co-localization, and interaction between pERK1/2 and PGT proteins in endometrial LE cells in vivo. Results demonstrate that IFNT induces activation of $\mathrm{pERK} 1 / 2$ proteins and increases its interaction with PGT protein, whereas co-treatment with ERK1/2 inhibitor (U0126) and IFNT decreases interaction between pERK1/2 and PGT protein in the endometrial LE and restores 3 to 4 pulses of $\mathrm{PGF}_{2 \alpha}$ (Lee et al., 2014). These results 
clearly indicate that IFNT interacts with PGT through ERK1/2 pathways and inhibits PGT-mediated release of $\mathrm{PGF}_{2 \alpha}$ from endometrial LE in sheep in vivo (Lee et al., 2014). Restoration of $\mathrm{PGF}_{2 \alpha}$ pulses in the IFNT and ERK1/2 inhibitor-treated group is positively associated with the expression of OXTR and ESR1 and negatively associated with the expression of p-ERK1/2 proteins in endometrial LE cells (Lee et al., 2014). These results suggest an important interplay among IFNT, ESR1, and OXTR through ERK1/2 pathways in endometrial LE cells in sheep. The underlying molecular pathways through which inhibition of ERK1/2 pathways reestablishes expression of OXTR and ESR1 in sheep are not presently known.

Earlier studies have proposed that IFNT suppresses ESR1 and OXTR through IRF2-dependent mechanisms in endometrial LE in sheep (Spencer et al., 2004, 1995c, 1998). However, the cell signaling pathways through which IFNT induces IRF-2 protein in endometrial LE are yet to be established. Our present results indicate that IFNT does not induce IRF-2 protein, and cotreatment of ERK1/2 inhibitor with IFNT does not modulate expression of IRF2 protein in endometrial LE cells on d 16 of the estrous cycle. Early pioneering work reported in one study that IFNT induced expression of IRF-2 protein in endometrial LE cells (Spencer et al., 1998); in contrast, the same researchers reported in their next study that IFNT did not induce expression of IRF-2 protein in endometrial LE in cyclic sheep (Choi et al., 2001). Taken together, our present results along with a previous study (Choi et al., 2001) suggest that IFNT suppresses ESR1 and OXTR through yet unidentified mechanisms independent of IRF2 pathways in endometrial LE at the time of MRP. In a later study, Bazer and coworkers reported that IFNT precludes binding of ESR1/SP1 with GC-rich regions of the OXTR promoter and thereby indirectly inhibits transcription of OXTR genes through ESR1/ SP1 complex (Fleming et al., 2006). We have recently identified that IFNT activates JAK-SRC-EGFR-RASRAF-ERK1/2-EGR-1 novel signaling pathways in endometrial LE cells in vitro (Banu et al., 2010), and that IFNT increases pERK1/2 and EGR-1 proteins in endometrial LE in vivo in sheep. Both EGR-1 and SP1 are competing for the same GC-rich element, and EGR1 acts as a tissue-specific transcriptional suppressor or activator of various genes under different physiological and pathological conditions (Raychowdhury et al., 2002; Al-Sarraj et al., 2005; Fernandez-Alvarez et al., 2008). It is possible that IFNT suppresses ESR-1 and OXTR though EGR-1 at the time of the MRP in ruminants; further functional studies are required for confirmation. By contrast, in cows, ESR1 is expressed in LE cells on d 12 to 14 of pregnancy. Whether suppression of ESR1 gene is required for IFNT to suppress OXTR gene has yet to be established in cows (Mann et al., 1999).

\section{Transport of IFNT from the Uterus to Ovary Through UOP at MRP in Ruminants}

Intrauterine infusions of IFNT in cyclic sheep and cows suppress endometrial pulses of $\mathrm{PGF}_{2 \alpha}$ and prevent luteolysis (Spencer et al., 1995a,b,c). Recent studies reported that infusion of IFNT $(200 \mu \mathrm{g} / \mathrm{d})$ into the uterine vein maintained functional CL in $80 \%$ of sheep up to $32 \mathrm{~d}$ through yet unidentified physiological mechanisms (Oliveira et al., 2008; Bott et al., 2010). As suggested by those authors, this could be due to increased intraluteal $\mathrm{PGE}_{2}$ biosynthesis or luteal immune cell activation but this end-point was not measured. In another study (Antoniazzi et al., 2013), the authors showed that infusion of 20 or $200 \mu \mathrm{g}$ of IFNT into the uterine vein or $200 \mu \mathrm{g}$ into the jugular vein protects the CL from the luteolytic action of $\mathrm{PGF}_{2 \alpha}$, irrespective of dose or route of administration in sheep. Further, that group of investigators concluded that IFNT is released from the uterus into the uterine vein and acts through an endocrine mechanism to induce ISG in the CL and thus delays luteolysis (Oliveira et al., 2008; Bott et al., 2010). However, pioneering work by Roberts and colleagues (Godkin et al., 1984) indicated that intrauterine infusion of ${ }^{125}$ I-labeled ovine trophoblast protein-1 (oTP-1, later named IFNT) into d-12 nonpregnant ewes is retained within the uterus. Only very small amounts of subunits of ${ }^{125} \mathrm{I}$ oTP-1 but not intact ${ }^{125} \mathrm{I}$ oTP-1 protein appeared to enter the maternal vasculature. We examined the transport of IFNT from the uterus to the ovary through the uterine vein-UOP-ovarian artery vascular route on d 12 to 16 of the estrous cycle and pregnancy in sheep. Western blot and ELISA (sensitivity of the assay was $1 \mathrm{ng} / \mathrm{mL}$, IFNT antibody, a generous gift from Fuller W. Bazer, Texas A\&M University) analyses indicate that IFNT protein is abundantly present in uterine flushing but it is not detectable in the utero-ovarian vein, ovarian artery, and CL on d 12 to 16 of pregnancy.

Hansen and colleagues, in their first report, used an antiviral assay that was not specific for IFNT (Oliveira et al., 2008). In their second report (Bott et al., 2010), they used roIFNT antibody to preabsorb d 15 uterine venous blood samples but in their ELISA, they used type 1 IFN instead of roINFT as their antigen and standard. Thus, in these 2 studies, they measured type 1 IFN but not IFNT per se in their samples. In their third study (Romero et al., 2015), they used roIFNT antibody and RIA, and detected IFNT in uterine venous 
blood of approximately 250 to $275 \mathrm{pg} / \mathrm{mL}$ (sensitivity of the assay was $148 \mathrm{pg} / \mathrm{mL}$ ). The data sets on the presence of IFNT in uterine venous blood in sheep at the time of MRP from these research groups (Godkin et al., 1984; Oliveira et al., 2008; Bott et al., 2010; Lee et al., 2012b; Romero et al., 2015) do not agree with each other. The reasons for this discrepancy are most likely model, approach, methodology, and sensitivity of the assays used. It is possible that very small amount $(0.2-0.3 \mathrm{ng} / \mathrm{mL})$ of IFNT escapes from the gravid uterus into uterine venous blood at the time of MRP or ESP in sheep. It is estimated that daily IFNT production by a d-14 ovine conceptus is about $600 \mathrm{ng} / \mathrm{h}$ or $14.4 \mu \mathrm{g} / \mathrm{d}$ (Ashworth and Bazer, 1989). Compared with large amounts of IFNT retained inside the uterus, the physiological importance of a small amount of IFNT $(0.2-0.3 \mathrm{ng} / \mathrm{mL})$ released into the uterine venous blood during MRP or ESP still needs be established.

Early experiments involving anastomosis of the uterine vein to the ovarian artery from the pregnant to the nonpregnant uterine horn indicate that both luteolytic and luteoprotective mediators need to be transported from the uterine vein to the ovarian artery via the UOP in sheep and cattle (Mapletoft and Ginther, 1975; Mapletoft et al., 1975, 1976a,b; Ginther, 1981). Furthermore, embryo/conceptus transfer and hysterectomy experiments indicate that the luteolytic and luteoprotective mechanisms are locally mediated between uterus and CL of the ipsilateral ovary and do not act systemically in sheep (Moor and Rowson, 1964, 1966a,b,c; Rowson and Moor, 1967; Moor et al., 1969, 1970). Interferon tau is a relatively large protein $(19 \mathrm{kDa})$ and it could not be transferred locally from the uterus to the ovary via the UOP. Hansen and collogues failed to show the presence of IFNT protein in the ovarian arterial blood or corpus luteum per se or to confirm the transport of IFNT through uterine vein-UOP-ovarian artery vascular route in their series of studies (Oliveira et al., 2008; Bott et al., 2010; Romero et al., 2015). The local action of the embryonic antiluteolytic or luteoprotective effect does call into question the physiological relevance of any protein that is not locally transported from the gravid uterus to the CL on luteal maintenance in ruminants (Silvia and Niswender, 1986).

Infusions of roIFNT into uterine vein increased levels of ISG15 mRNA in the CL (Oliveira et al., 2008; Bott et al., 2010), suggesting that high levels of IFNT in the circulating blood may cause such an increase either directly or indirectly by downstream mediators. Previous studies from 2 different laboratories showed that subcutaneous (Spencer et al., 1999) and intramuscular (Chen et al., 2006) injections of $2 \mathrm{mg}$ of roIFNT from d 11 to 17 of the estrous cycle increased expression of ISG15 mRNA in the CL in sheep, which supports the systemic action of IFNT on peripheral tissues. However, none of the systemic administration of roIFNT delivery induced an extended delay in return to estrus in sheep (Spencer et al., 1999; Chen et al., 2006), suggesting that expression of ISG15 is not associated with antiluteolytic action of IFNT.

In contrast, Hansen and colleagues recently reported (Antoniazzi et al., 2013) that infusion of IFNT (20 or $200 \mu \mathrm{g})$ into the uterine vein or administration of IFNT $(200 \mu \mathrm{g})$ into the jugular vein, regardless of route or dose, effectively protects CL from the luteolytic actions of $\mathrm{PGF}_{2 \alpha}$ by mechanisms that may involve luteal ISG and stabilization of cell survival genes. Further functional studies are required to resolve these conflicting findings on the role of ISG in luteal maintenance in sheep or cows. On the other hand, a recent study by Spencer and colleagues (Dorniak et al., 2011) indicated that IFNT increased ISG15 mRNA in the endometrium on d 10 to 14 of the estrous cycle and this effect was abolished by co-infusion of the COX-2 inhibitor meloxicam in sheep. These data suggest that IFNT increases expression of ISG15 mRNA in the endometrium indirectly through COX-2-derived $\mathrm{PG}$, presumably $\mathrm{PGE}_{2}$. A recent study by Spencer et al. (2013) indicated that $\mathrm{PG}$, including $\mathrm{PGE}_{2}$, directly increased ISG15 mRNA in the endometrium in cows and sheep. Thus, it is possible that uterine venous or systemic administrations of roIFNT may reach the ovary through the systemic circulation and interact with type 1 IFN receptors and either directly increase ISG15 mRNA or indirectly increase it by stimulating intraluteal $\mathrm{PGE}_{2}$ production, which was not measured by Hansen and colleagues in their studies (Oliveira et al., 2008; Bott et al., 2010; Antoniazzi et al., 2013). Thus, further work will be required to determine the physiological significance of uterine venous IFNT in sheep and mechanisms by which uterine venous administrations of IFNT maintain luteal structure and function.

\section{Source and Origin of a Luteoprotective Mediator During MRP in Ruminants}

In ruminants, the CL of early pregnancy is more resistant to the luteolytic action of $\mathrm{PGF}_{2 \alpha}$ (Inskeep et al., 1975; Pratt et al., 1977; Nancarrow et al., 1982; Silvia and Niswender, 1984, 1986) on d 12 to 16, and the resistance is even greater when multiple embryos are present (Nancarrow et al., 1982). Injection of $\mathrm{PGF}_{2 \alpha}$ into the ovarian artery or follicles of early pregnant sheep causes luteolysis in 28 or $17 \%$ of animals compared with 78 or $83 \%$ in nonpregnant sheep, respectively (Inskeep et al., 1975; Pratt et al., 1977). Exogenous estradiol at doses causing premature luteolysis in cyclic sheep is less effective in pregnant sheep (Kittok and Britt, 1977). 
In hysterectomy (Anderson et al., 1969; Ginther, 1981; McCracken et al., 1999; Moor et al., 1970) and ovarian transplant models (McCracken et al., 1971, 1973, 1999) in sheep, the CL is maintained for $>100 \mathrm{~d}$, which is due to the absence of endometrial $\mathrm{PGF}_{2 \alpha}$ pulses in the hysterectomy model and the failure of endometrial luteolytic $\mathrm{PGF}_{2 \alpha}$ pulses to reach the ovary locally via UOP in the ovarian transplant model (Anderson et al., 1969; Moor et al., 1970; McCracken et al., 1971, 1973, 1999; Ginther, 1981). Although the CL is maintained in both of these models, it regresses readily to exogenous $\mathrm{PGF}_{2 \alpha}$ (McCracken et al., 1971, 1973, 1999). In contrast, the $\mathrm{CL}$ in early pregnancy is resistant to exogenous $\mathrm{PGF}_{2 \alpha}$ and the pregnancy is maintained (Inskeep et al., 1975; Mapletoft et al., 1976a; Pratt et al., 1977; Nancarrow et al., 1982; Silvia and Niswender, 1984, 1986). Early studies have indicated that during the ESP in sheep, a factor(s) from the conceptus or gravid uterus reaches the ovary locally through the UOP and protects the CL from luteolysis (Moor and Rowson, 1966a,b; Moor et al., 1969; Mapletoft and Ginther, 1975, Mapletoft et al., 1975, 1976a; Silvia and Niswender, 1986). In sheep, secretion of $\mathrm{PGE}_{2}$ from the uterus into the uterine vein increases during the period of luteal resistance in early pregnancy on d 12 to 16 (Lewis et al., 1978, Ellinwood et al., 1979, Silvia et al., 1984; Silvia and Niswender, 1984, 1986; Rawlings and Hyland, 1985; Vincent and Inskeep, 1986; Vincent et al., 1986). Intraovarian administration of $\mathrm{PGE}_{2}$ at certain doses counteracts the luteolytic actions of $\mathrm{PGF}_{2 \alpha}$ (Henderson et al., 1977). Prostaglandin $\mathrm{E}_{2}$ is secreted by both conceptus (Hyland et al., 1982; Lacroix and Kann, 1982; Charpigny et al., 1997) and endometrium in vitro (Ellinwood et al., 1979; Marcus, 1981; Lacroix and Kann, 1982) from pregnant ewes. Intrauterine or intraovarian infusions of $\mathrm{PGE}_{2}$ in nonpregnant ewes extend the interestrus interval and reduce luteal sensitivity to both endogenously secreted and exogenously administered $\mathrm{PGF}_{2 \alpha}$ (Henderson et al., 1977, Pratt et al., 1977, 1979; Magness et al., 1981; Reynolds et al., 1981). Similar effects of uterine infusion of $\mathrm{PGE}_{2}$ have been observed in cows (Reynolds et al., 1983). Prostaglandin $\mathrm{E}_{2}$ is a lipid-soluble mediator with a low molecular weight of $0.35 \mathrm{kDa}$ and is structurally similar to $\mathrm{PGF}_{2 \alpha}$, which most likely can be transported locally from the uterus to the ovary (Silvia and Niswender, 1986) through PGT-mediated mechanisms in the UOP (Banu et al., 2003; Lee et al., 2010). As a stimulator of cAMP and a vasodilator, $\mathrm{PGE}_{2}$ has properties that are opposite to that of $\mathrm{PGF}_{2 \alpha}$ (McCracken et al., 1999). Thus, $\mathrm{PGE}_{2}$ may be one of the factors that protect the CL from luteolysis during MRP or ESP in ruminants. The review by Weems et al. (2006) provides more detail on the role for $\mathrm{PGE}_{2}$ on luteal protection in ruminants.

\section{Selective and Preferential Transport of $P G F_{2 \alpha}$ and $P G E_{2}$ from the Uterus to the Ovary Through the UOP During Luteolysis and MRP in Ruminants}

Endometrial production of $\mathrm{PGF}_{2 \alpha}$ peaks on $\mathrm{d} 14$ to 15 after estrus in both pregnant and nonpregnant sheep (Hooper et al., 1986; Zarco et al., 1988). Nonpregnant sheep display pulsatile release of $\mathrm{PGF}_{2 \alpha}$ superimposed on a constant baseline, whereas pregnant sheep show increased continuous basal release of $\mathrm{PGF}_{2 \alpha}$ (Zarco et al., 1988). During the period of MRP, one of the fascinating aspects is that pulsatile release of $\mathrm{PGF}_{2 \alpha}$ is inhibited, whereas the basal concentration of $\mathrm{PGF}_{2 \alpha}$ is increased in pregnant compared with nonpregnant sheep (Hooper et al., 1986; Zarco et al., 1988). We have shown that the pulsatile release of $\mathrm{PGF}_{2 \alpha}$ is regulated by central oxytocin release and PGT-mediated transport, whereas the basal release of $\mathrm{PGF}_{2 \alpha}$ is controlled by simple diffusion in sheep (Banu et al., 2008; Lee et al., 2013).

Concentrations of $\mathrm{PGE}_{2}$ and $\mathrm{PGF}_{2 \alpha}$ are increased in uterine venous plasma at the time of ESP in sheep (Lewis et al., 1978; Ellinwood et al., 1979; Silvia et al., 1984; Silvia and Niswender, 1984, 1986; Rawlings and Hyland, 1985; Vincent and Inskeep, 1986). We determined the transport of $\mathrm{PGE}_{2}$ and $\mathrm{PGF}_{2 \alpha}$ from the uterus to the ovary through the uterine vein-UOPovarian artery vascular route on d 12 to 16 of the estrous cycle and pregnancy in sheep (Lee et al., 2012b). The intrauterine concentration of $\mathrm{PGF}_{2 \alpha}$ is significantly higher compared with that of $\mathrm{PGE}_{2}$ on $\mathrm{d} 16$ of the estrous cycle and pregnancy. Importantly, $\sim 85 \%$ of $\mathrm{PGF}_{2 \alpha}$ is transported from the uterus to the uterine vein at the time of luteolysis, whereas only $\sim 35 \%$ of $\mathrm{PGF}_{2 \alpha}$ is transported from the uterus to the uterine vein at the time of MRP or ESP. These results indicate that $\mathrm{PGF}_{2 \alpha}$ is secreted and transported from the endometrium to the uterine vein (endocrine secretion) at the time of luteolysis and from the endometrium to the uterine lumen (exocrine secretion) at the time of MRP or ESP in ruminants, as has been proposed in pigs (Bazer and Thatcher, 1977). It is possible that PGT (Banu et al., 2003, 2008, 2010), either individually or in coordination with other transporters such as MRP4 (Reid et al., 2003), could regulate this endocrine versus exocrine transport of $\mathrm{PGF}_{2 \alpha}$ in ruminant endometrium. Functional studies are needed to understand this important mechanism.

Prostaglandin $E_{2}$ is preferentially transported from the uterus to the ovary at the time of ESP. The concentration of $\mathrm{PGE}_{2}$ is higher in the uterine vein ( $\sim 30$ vs. $\sim 0.5 \mathrm{ng} / \mathrm{mL}$ ) and in the ovarian artery ( $\sim 4$ vs. $\sim 0.5 \mathrm{ng} /$ $\mathrm{mL}$ ) on $\mathrm{d} 16$ of pregnancy compared with that of the estrous cycle, respectively (Lee et al., 2012b). Our pres- 
ent data are in agreement with several previous findings that secretion of $\mathrm{PGE}_{2}$ from the uterus into the uterine vein increases during the period of luteal resistance in early pregnancy in sheep (Lewis et al., 1978; Ellinwood et al., 1979; Silvia et al., 1984; Silvia and Niswender, 1984, 1986; Rawlings and Hyland, 1985; Vincent and Inskeep, 1986; Vincent et al., 1986). Transport of $\mathrm{PGE}_{2}$ from the uterus to the uterine vein and from the uterine vein to the ovarian artery appears to depend on its net concentration present in the uterine lumen and uterine vein, respectively. These results suggest that $\mathrm{PGE}_{2}$ is transported from the uterus to the ovary selectively or preferentially and not regulated by endocrine-exocrine secretory mechanisms at the time of luteolysis versus MRP or ESP in sheep.

\section{Selective Luteal $P G F_{2 \alpha}$ and $P G E_{2}$ Biosynthesis and Signaling During Luteolysis and MRP in Ruminants}

We determined the regulation of $\mathrm{PGF}_{2 \alpha}$ and $\mathrm{PGE}_{2}$ biosynthesis and signaling components in the CL on d 12 to 16 of the estrous cycle and pregnancy (Lee et al., 2012b). Our results indicate that the ratio between AKR1B1-PGFS and PGES-1 or PGES-3 is higher on d 14 to 16 of the estrous cycle. In contrast, the ratio between PGES-1 or PGES-3 and AKR1B1-PGFS is higher on d 14 to 16 of pregnancy (Lee et al., 2012b). To evaluate the functional aspects of these enzymatic changes, we measured luteal production and secretion of $\mathrm{PGF}_{2 \alpha}$ and $\mathrm{PGE}_{2}$. The ratio of $\mathrm{PGF}_{2 \alpha}$ to $\mathrm{PGE}_{2}$ in the ovarian venous plasma is higher on d 14 and 16 of the estrous cycle, whereas the ratio of $\mathrm{PGE}_{2}$ to $\mathrm{PGF}_{2 \alpha}$ is increased on $\mathrm{d} 14$ and 16 of pregnancy (Lee et al., 2012b). Analyses of luteal lysates indicate that intraluteal production of $\mathrm{PGF}_{2 \alpha}$ is higher on $\mathrm{d} 16$ of the estrous cycle, whereas intraluteal $\mathrm{PGE}_{2}$ production is increased on d 16 of pregnancy (Lee et al., 2012b). Data from the CL explant tissue cultures indicate that $\mathrm{PGH}_{2}$ is selectively converted to $\mathrm{PGF}_{2 \alpha}$ on $\mathrm{d} 16$ of the estrous cycle, whereas $\mathrm{PGH}_{2}$ is selectively converted to $\mathrm{PGE}_{2}$ on d 16 of pregnancy (Lee et al., 2012b). These results together indicate that luteal $\mathrm{PG}$ biosynthesis is selectively directed toward $\mathrm{PGF}_{2 \alpha}$ at the time of luteolysis and toward $\mathrm{PGE}_{2}$ at the time of ESP. Our present results support previous reports that PGES-1 protein is highly expressed in the CL at the time of ESP in cows (Arosh et al., 2003), and that exogenous administration of $\mathrm{PGF}_{2 \alpha}$ increases the ratio of PGES-1 to PGFS-AKR1B1 mRNA in luteal tissue on d 12 in pregnant compared with cyclic sheep (Costine et al., 2007).

Earlier studies reported that administration of $\mathrm{PGF}_{2 \alpha}$ on d 11 or 12 of the estrous cycle induced expression of COX-2 mRNA in the luteal tissues at 1 to $4 \mathrm{~h}$ but it returned to basal level at 12 and $24 \mathrm{~h}$ in sheep (Tsai and Wiltbank, 1997, 1998). Our recent results indicate that COX-2 protein is constantly expressed in the CL on d 12 to 16 of the estrous cycle and pregnancy. Expression of COX-2 is required for both $\mathrm{PGF}_{2 \alpha}$ and $\mathrm{PGE}_{2}$ biosynthesis. Whereas PGES-1 is functionally coupled to COX-2 and controls $>90 \%$ of total $\mathrm{PGE}_{2}$ production, PGES-2 is preferentially coupled to constitutive COX-1, and PGES-3 is coupled to both COX-1 and COX-2 (Kudo and Murakami, 1999; Thorén and Jakobsson, 2000) depending on the need. Our results indicate that the COX-2-AKR1B1-PGFS pathway is involved in luteal $\mathrm{PGF}_{2 \alpha}$ biosynthesis at the time of luteolysis; in contrast, the COX-2-PGES-1/PGES-3 pathway is involved in luteal $\mathrm{PGE}_{2}$ biosynthesis during the ESP (Lee et al., 2012b).

The net luteal production of $\mathrm{PGF}_{2 \alpha}$ versus $\mathrm{PGE}_{2}$ is regulated not only by biosynthetic enzymes but also by the catabolic enzyme PGDH. Our results (Lee et al., 2012b) indicate that PGDH protein is highly expressed on d 12 to 16 of pregnancy but not on d 12 to 16 of the estrous cycle in sheep. To determine the functional aspects of luteal PGDH in vivo, we measured the concentrations of PGFM and PGEM in the ovarian venous plasma. The concentration of PGFM is higher on $\mathrm{d} 14$ and 16 of pregnancy compared with that of the estrous cycle. Surprisingly, the concentration of PGEM is very low and does not appear to be regulated (Lee et al., 2012b). Three isoforms of PGDH are identified and these isoforms are differentially expressed in human placental tissues (McCracken et al., 2012) and their functions are not completely understood. The action of $\mathrm{PGDH}$ on $\mathrm{PGF}_{2 \alpha}$ catabolism is well supported in the ovine CL (Silva et al., 2000); however, the action of PGDH on $\mathrm{PGE}_{2}$ catabolism is largely unknown. Our result suggests that the PGDH protein detected at $29 \mathrm{kDa}$ in the ovine CL catabolizes only $\mathrm{PGF}_{2 \alpha}$ into PGFM but not $\mathrm{PGE}_{2}$ into PGEM during early pregnancy. We believe that other PGDH isoforms yet to be characterized or discovered may control the catabolism of $\mathrm{PGE}_{2}$ to $\mathrm{PGEM}$ in the ovine CL. Our recent results support previous findings that PGDH mRNA expression is increased in the CL on d 13 to 14 of pregnancy compared with that of the estrous cycle in sheep, and this increase is critical for catabolism of $\mathrm{PGF}_{2 \alpha}$ by the CL of early pregnancy (Silva et al., 2000). These results together indicate that intraluteal $\mathrm{PGF}_{2 \alpha}$ production at the time of luteolysis is governed by increased ratios of AKR1B1-PGFS to PGES-1 and PGES-3, whereas the increased intraluteal $\mathrm{PGE}_{2}$ production at the time of ESP is governed by increased ratios of PGES-1 and PGES-3 to AKR1B1-PGFS and increased PGF $_{2 \alpha}$ catabolism by PGDH (Lee et al., 2012b). 
I. Luteolysis

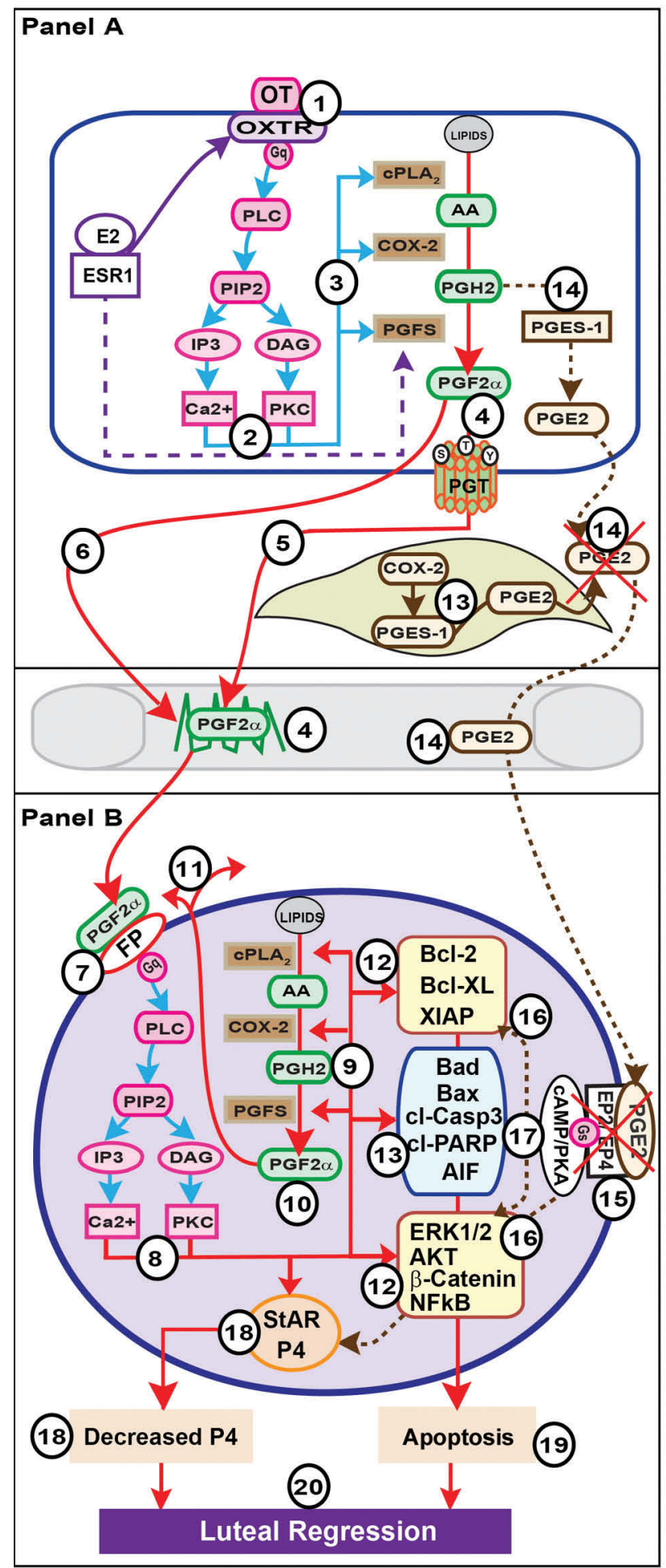

II. MRP

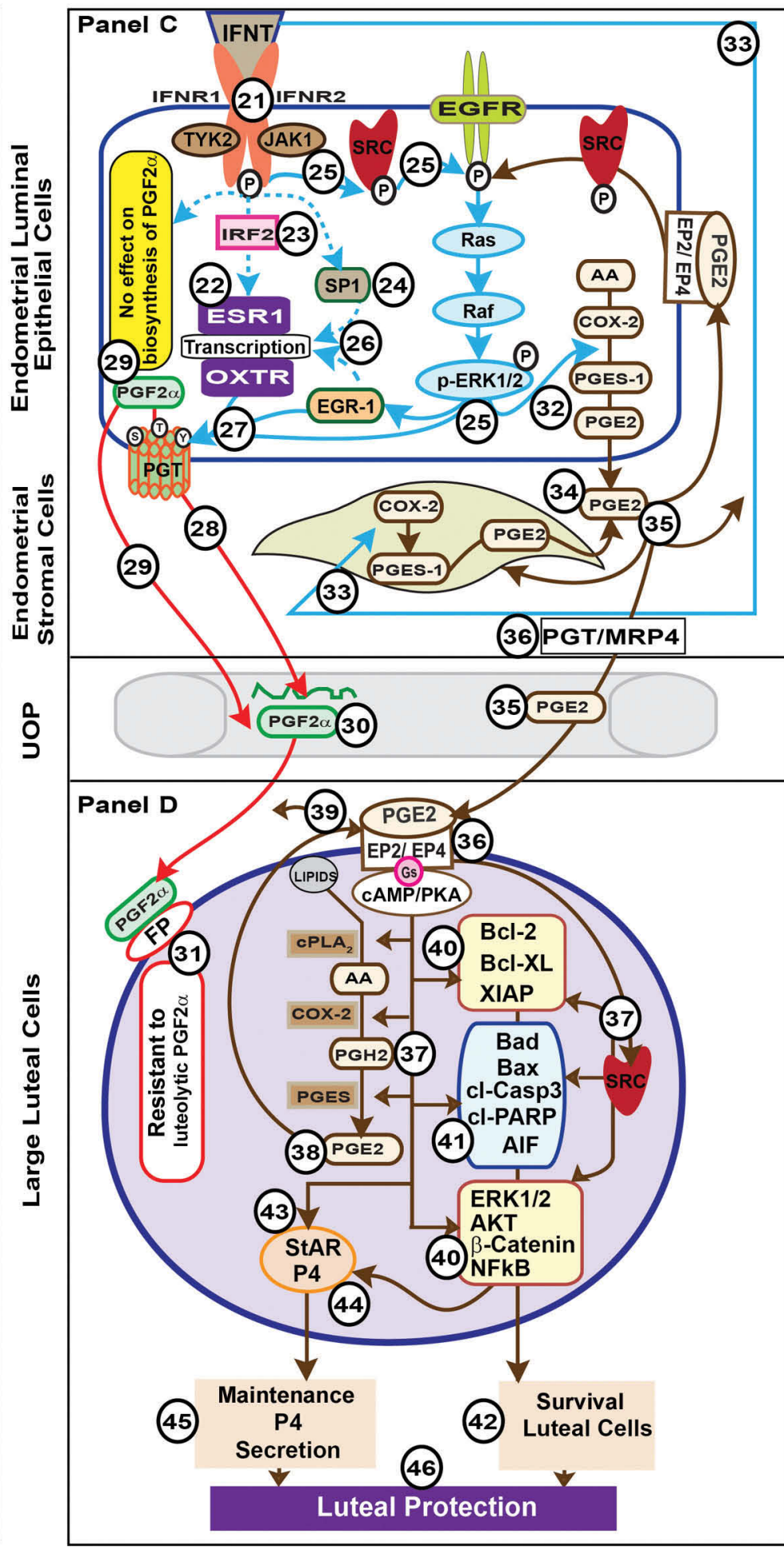

Figure 2. Caption on facing page. 
Figure 2. Working model on novel concepts on action of prostaglandins (PG) on luteal maintenance and maternal recognition of pregnancy (MRP) and establishment of pregnancy (ESP) in ruminants: (I) Luteolysis (panel A): (1) Oxytocin (OT) acts on its receptor OXTR, (2) activates $\mathrm{Ca}^{2+}$ and protein kinase $\mathrm{C}$ (PKC) pathways, (3) which in turn activates the endometrial $\mathrm{PGF}_{2 \alpha}$ biosynthetic machinery, and (4) induces endometrial $\mathrm{PGF}_{2 \alpha}$ production. Luteolytic $\mathrm{PGF}_{20}$ pulses are transported through (5) prostaglandin transport (PGT)-dependent mechanisms and basal release of $\mathrm{PGF}_{2 \alpha}$ is mediated through (6) PGT-independent mechanism or simple diffusion from the endometrial epithelial cells to the corpus luteum (CL) through the utero-ovarian plexus (UOP). (Panel B) Endometrial luteolytic PGF ${ }_{2 \alpha}$ pulses $(7)$ act on the PGF ${ }_{2 \alpha}$ receptor (FP) in large luteal cells, (8) activate $\mathrm{Ca}^{2+}$ and PKC pathways, (9) which in turn activates the luteal $\mathrm{PGF}_{2 \alpha}$ biosynthetic machinery, and (10) induces intraluteal $\mathrm{PGF}_{2 \alpha}$ production, and (11) further auto-amplifies luteal $\mathrm{PGF}_{2 \alpha}$ production by autocrine and paracrine mechanisms. In addition, $\mathrm{PGF}_{2 \alpha}-\mathrm{FP}$ signaling (12) suppresses survival pathways and (13) activates apoptotic pathways. (14) Importantly, endometrial PGE $\mathrm{E}_{2}$ production is suppressed at the time of luteolysis, which leads to (15) repressed $\mathrm{PGE}_{2}-\mathrm{EP} 2 / \mathrm{EP} 4\left(\mathrm{PGE}_{2}\right.$ receptor) signaling in large luteal cells, thus expediting (16) suppression of survival and (17) activation of apoptotic pathways in large luteal cells. Together, activation of FP and suppression of EP2/ EP4 signaling (18) decrease progesterone (P4) biosynthesis and secretion, (19) induce apoptosis of large luteal cells, which eventually culminates in (20) functional and structural luteolysis. II. MRP/ESP: (panel C) (21) Interferon-tau (IFNT) acts on its receptors IFNR1 and IFNR2 and (22) suppresses estrogen receptor $\alpha$ (ESR-1) and oxytocin receptor (OXTR) through (23) IFN regulatory factor-2 (IRF-2) or (24) specificity protein 1 (SP1) (sequential signaling cascades from IFNR to IRF2 or SP1 is yet to be confirmed). In parallel, IFNT activates (25) the IFNR-JAK-SRCEGFR-RAS-RAF-ERK1/2-EGR1 module. (26) early growth response protein 1 (EGR1) and SP1 are competing for the same GC-rich elements, and EGR1 may compete or replace binding with SP1 and suppresses OXTR (this mechanism yet to be confirmed). (27) ERK1/2 and EGR1 inhibits PGT function and (28) suppresses PGT-mediated transport of pulsatile release of PGF F $_{2}$ from the endometrium to the CL through the UOP. Interestingly, (29) IFNT does not inhibit basal endometrial production of $\mathrm{PGF}_{2 \alpha}$, which is transported by PGT-independent mechanism or simple diffusion from the endometrium to the UOP. It supports the increased basal concentration of PGF $\mathrm{F}_{2 \alpha}(30)$ found in the UOP at the time of ESP. (31) $\mathrm{PGF}_{2 \alpha}$ acts on the FP in the large luteal cells but the CL of early pregnancy is resistant to both basal and luteolytic PGF ${ }_{2 \alpha}$ action. Concurrently, IFNT acts on (32) the endometrial epithelial cells and (33) stromal cells through multiple mechanisms, (34) increases net endometrial $\mathrm{PGE}_{2}$ production, (35) which further auto-amplifies endometrial $\mathrm{PGE}_{2}$ production through autocrine/paracrine EP2/EP4 signaling. (36) $\mathrm{PGE}_{2}$ is transported from the endometrium to the CL through the UOP via PGT- or MRP4-mediated mechanisms. (Panel D) (37) Endometrial $\mathrm{PGE}_{2}$ acts on the EP2/EP4 in the large luteal cells, activates cAMP/PKA and SRC pathways, and in turn auto-amplifies (38) intraluteal $\mathrm{PGE}_{2}$ production via (39) autocrine and paracrine EP2/EP4 signaling. In parallel, EP2/EP4 signaling activates (40) antiapoptotic or survival pathways, (41) suppresses proapoptotic pathways, thus protecting the CL from structural luteolysis. $\mathrm{PGE}_{2}$ through (42) cAMP/protein kinase A (PKA) and (43) SRC-ERK1/2 or SRC-AKT pathways may drive the (44) constitutive production of progesterone by the large luteal cells and thus protects the CL from functional luteolysis. Collectively, (45) IFNT or pregnancy-induced endometrial PGE ${ }_{2}$ and luteal $\mathrm{PGE}_{2}$ promote resistance of the $\mathrm{CL}$ against $\mathrm{PGF}_{2 \alpha}$ through multiple intracellular mechanisms and protect the CL from regression during $\mathrm{MRP}$ or ESP. Note: Considering the focus of this review, we are not able to include other important signaling pathways such as nitric oxide, endothelin, cytokines, and antioxidants in the large luteal cells. Given the complexity of the signaling network, we limited our model to large luteal cells for clarity and readability. Color version available online.

Biosynthesized luteal $\mathrm{PGF}_{2 \alpha}$ and $\mathrm{PGE}_{2}$ need to be transported out of luteal cells and act through their specific receptors $\mathrm{FP}$ or EP, respectively, to produce their physiological effects. Prostaglandin transporter competitively transports $\mathrm{PGF}_{2 \alpha}$ and $\mathrm{PGE}_{2}$ with equal affinity (Banu et al., 2003). Our results indicate that expression of PGT protein in the CL is not regulated by the estrous cycle or pregnancy on d 12 to 16 . This constant expression of PGT suggests that the amount of PGT protein available to transport $\mathrm{PGF}_{2 \alpha}$ or $\mathrm{PGE}_{2}$ from luteal cells may not differ between luteolysis and ESP.

Our results (Lee et al., 2012b) further indicate that expression of FP protein in the CL on d 12 to 16 is also not regulated by the estrous cycle or pregnancy. Activation of FP in turn activates $\mathrm{PKC}, \mathrm{IP}_{3}$, and $\mathrm{Ca}^{2+}$ cell signaling pathways (Narumiya et al., 1999) and interacts with multiple intracellular cell signaling pathways in the luteal cells in sheep and cows (Wiltbank et al., 1995; Anderson et al., 2001; Davis and Rueda, 2002). Our present results support previous findings that FP numbers or FP mRNA in the CL are similar in cyclic and early pregnant sheep and that the resistance of the $\mathrm{CL}$ of early pregnancy to exogenous $\mathrm{PGF}_{2 \alpha}$ is appar- ently not due to a change in FP receptor concentration (Wiepz et al., 1992).

In addition, our results indicate that luteal EP2- and EP4-mediated $\mathrm{PGE}_{2}$ signaling is activated at the time of ESP, whereas it is suppressed or inhibited at the time of luteolysis (Lee et al., 2012b). Both EP2 and EP4 activate cAMP and PKA pathways. Expression of EP3 protein is marginally increased on d 12 and 14 of pregnancy compared with that of the estrous cycle. The 4 EP3 isoforms, EP3A, EP3B, EP3C, and EP3D, are produced by alternative splicing of the C-terminal, and show different efficiency in activation of the Gq, Gs, and Gi proteins and inhibition or stimulation of adenylate cyclase and cAMP (Narumiya et al., 1999). Activation of EP3A decreases cAMP, EP3B and EP3C increase cAMP, and EP3D decreases cAMP and increases $\mathrm{IP}_{3}$ (Narumiya et al., 1999). The commercially available EP3 antibody used in our study recognized $\mathrm{N}$-terminal but not C-terminal splices and thus specific EP3 isoforms were not detectable. However, a recent study in cows showed that expression of EP3B mRNA increased in the $\mathrm{CL}$ in response to $\mathrm{PGE}_{2}$ and was associated with maintenance of the CL (Weems et al., 2012). Further, our results show that expression of the 
EP1 protein in the CL is decreased on d 16 of pregnancy. Activation of EP1 activates $\mathrm{PKC}, \mathrm{IP}_{3}$, and $\mathrm{Ca}^{2+}$ cell signaling pathways (Narumiya et al., 1999). The results suggest that luteal $\mathrm{PGE}_{2}$ signaling is specifically directed toward cAMP-PKA pathways through EP2, EP4, and EP3B subtypes during the ESP in ruminants (Lee et al., 2012b; Weems et al., 2012). It is possible that EP2, EP4, and EP3B could activate or share the common cAMP-PKA intracellular pathways in the ovine CL. However, this is yet to be determined by receptor-specific functional studies.

\section{Selective Cell Survival and Apoptosis Signaling in the CL During Luteolysis and MRP in Ruminants}

We determined the regulation of important components of survival and apoptotic pathway networks in the ovine CL (Lee et al., 2015). We found that p-ERK1/2, p-AKT, $\beta$-catenin, p-NFkB, p-Src 416 , p- $\beta$-arrestin, and p-GSK3 $\beta$ signaling proteins are temporally suppressed in the CL from d 14 to 16 of the estrous cycle. By contrast at time of ESP, expression or activation of

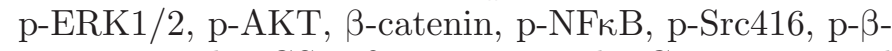
arrestin, and p-GSK3 $\beta$ proteins in the CL is sustained or increased on d 12 to 16 to maintain its function and structure. Our results further demonstrate that expression of Bcl-XL, Bcl2, Bad, and Bax proteins are not regulated in the CL on d 12 to 16 of the estrous cycle. In contrast, expression of cleaved (active) caspase-3 and apoptosis-induction factor (AIF) proteins are increased and $\mathrm{x}$-linked inhibitor of apoptosis protein (XIAP) protein is decreased in the CL on d 16 of the estrous cycle. By contrast, expression of Bcl2, Bcl-XL, and XIAP proteins are sustained or increased, and activation of caspase-3 protein is suppressed in the CL on d 12 to 16 of pregnancy (Lee et al., 2015). These results together indicate that programmed suppression of cell survival pathways and programmed activation of caspase-3 dependent and independent intrinsic apoptotic pathways are required for luteolysis. Whereas, these multiple and redundant cell survival and antiapoptotic pathways need to be sustained and proapoptotic proteins need to be suppressed to rescue the CL from functional as well as structural luteolysis at the time of MRP or ESP (Lee et al., 2015). Prostaglandin $\mathrm{E}_{2}$ acts a mitogenic, antiapoptotic, angiogenic, steroidogenic, and immunomodulatory mediator in diverse systems (Clevers, 2006; Wang and Dubois, 2006; Cha and DuBois, 2007; Eisinger et al., 2007). In addition, our results indicate that luteal EP2- and EP4-mediated $\mathrm{PGE}_{2}$ signaling is activated at the time of ESP and suppressed or inhibited at the time of luteolysis (Lee et al., 2012b). Prostaglandin $\mathrm{E}_{2}$ activates ERK1/2, AKT, $\beta$-catenin, and NFkB pathways in tumor cells (Castellone et al.,
2005; Buchanan et al., 2006; Cha and DuBois, 2007) and various other cell types (Banu et al., 2009). Thus, activation of EP2 and EP4 may be one of the critical mechanisms to protect the CL of early pregnancy from luteolytic challenges in ruminants. Our ongoing studies will identify interactions between $\mathrm{PGE}_{2} \mathrm{EP} 2 /$ EP4 signaling and cell survival and apoptosis protein machinery in the CL during MRP or ESP in ruminants.

\section{Novel Concepts on $P G E_{2}$ Signaling on Luteal Maintenance During MRP in Ruminants}

In our ongoing studies, we find that IFNT increases expression of PGES-1 in endometrial epithelium in sheep. Intrauterine co-administration of IFNT and PGES-1 inhibitor restores expression of ESR-1 and OXTR, reestablishes endometrial $\mathrm{PGF}_{2 \alpha}$ pulses, and causes luteolysis. By contrast, intrauterine co-administration of IFNT and PGES-1 inhibitor along with intraovarian administration of $\mathrm{PGE}_{2}$ rescues the CL. These results suggest that, in addition to suppression of endometrial $\mathrm{PGF}_{2 \alpha}$ pulses, IFNT may prolong the lifespan of the CL by increasing endometrial secretion of $\mathrm{PGE}_{2}$, which in turn increases luteal $\mathrm{PGE}_{2}$ biosynthesis and signaling and thus promotes luteal resistance. We have reported that IFNT or early pregnancy increases expression of EP2 and EP4 in the endometrial LE on d 12 to 16 in sheep (Lee et al., 2012a). Interferon tau increases the concentration of $\mathrm{PGE}_{2}$ in uterine flushing and utero-ovarian vein in sheep (Arosh et al., 2011). Intrauterine infusion of EP2 and EP4 inhibitors decreases IFNT production and constrains the elongation of the conceptus on d 16 of pregnancy in sheep (Nithy et al., 2011). These emerging studies together suggest possible interactions between IFNT and EP2/EP4 signaling in the endometrium in ruminants.

\section{CONCLUDING REMARKS AND IMPLICATIONS}

Accumulating information provides compelling evidence that $\mathrm{PGE}_{2}$ produced by the $\mathrm{CL}$ in response to endometrial $\mathrm{PGE}_{2}$ induced by IFNT or pregnancy may act as a luteoprotective mechanism and thus prolong the lifespan of the CL during MRP and ESP in ruminants. The potential mechanisms are depicted in Figure 2. Further functional studies are required to uncover these underlying molecular and cellular mechanisms. It is evident that antiluteolytic and luteoprotective mechanisms are complementary, and both mechanisms are required to rescue and protect the CL at the time of MRP and ESP. Deregulation of either one of the mechanisms may cause premature functional as well as structural luteolysis and thus lead to a compromised pregnancy in ruminants. Targeting $\mathrm{PGE}_{2}$ biosynthesis 
and signaling selectively in the endometrium or CL is expected to provide luteoprotective therapy to improve reproductive efficiency in ruminants.

\section{ACKNOWLEDGMENTS}

Part of the data discussed in the review was supported by Agriculture and Food Research Initiative Competitive Grants \#2008-35203-19101 and \#201367015-20967 from the USDA National Institute of Food and Agriculture (Washington, DC) to J. A. A. The authors have nothing to disclose.

\section{REFERENCES}

Al-Sarraj, A., R. M. Day, and G. Thiel. 2005. Specificity of transcriptional regulation by the zinc finger transcription factors $\mathrm{Sp} 1, \mathrm{Sp} 3$, and Egr-1. J. Cell. Biochem. 94:153-167.

Anderson, L. E., Y. L. Wu, S. J. Tsai, and M. C. Wiltbank. 2001. Prostaglandin $\mathrm{F}$ (2alpha) receptor in the corpus luteum: Recent information on the gene, messenger ribonucleic acid, and protein. Biol. Reprod. 64:1041-1047.

Anderson, L. L., K. P. Bland, and R. M. Melampy. 1969. Comparative aspects of uterine-luteal relationships. Recent Prog. Horm. Res. 25:57-104.

Antoniazzi, A. Q., B. T. Webb, J. J. Romero, R. L. Ashley, N. P. Smirnova, L. E. Henkes, R. C. Bott, J. F. Oliveira, G. D. Niswender, F. W. Bazer, and T. R. Hansen. 2013. Endocrine delivery of interferon tau protects the corpus luteum from prostaglandin F2 alphainduced luteolysis in ewes. Biol. Reprod. 88:144.

Arosh, J. A., S. K. Banu, P. Chapdelaine, V. Emond, J. J. Kim, L. A. MacLaren, and M. A. Fortier. 2003. Molecular cloning and characterization of bovine prostaglandin E2 receptors EP2 and EP4: Expression and regulation in endometrium and myometrium during the estrous cycle and early pregnancy. Endocrinology 144:3076-3091.

Arosh, J. A., J. Lee, S. S. Stephen, J. A. Stanley, B. Yang, T. K. Nithy, S. K. Banu, and J. A. McCracken. 2011. Intrauterine infusion of interferon tau selectively directs intraluteal prostaglandin biosynthesis towards PGE2 and activates EP2 and EP4-mediated signaling in the corpus luteum at the time of establishment of pregnancy in ruminants. Biol. Reprod. Suppl. 85(Suppl. 1):373. (Abstr.)

Ashworth, C. J., and F. W. Bazer. 1989. Changes in ovine conceptus and endometrial function following asynchronous embryo transfer or administration of progesterone. Biol. Reprod. 40:425-433.

Banu, S. K., J. A. Arosh, P. Chapdelaine, and M. A. Fortier. 2003. Molecular cloning and spatio-temporal expression of the prostaglandin transporter: A basis for the action of prostaglandins in the bovine reproductive system. Proc. Natl. Acad. Sci. USA 100:11747-11752.

Banu, S. K., J. Lee, M. C. Satterfield, T. E. Spencer, F. W. Bazer, and J. A. Arosh. 2008. Molecular cloning and characterization of prostaglandin transporter in ovine endometrium: Role of mitogen activated protein kinase pathways in release of prostaglandin F2 alpha. Endocrinology 149:219-231.

Banu, S. K., J. Lee, V. O. Speights Jr., A. Starzinski-Powitz, and J. A. Arosh. 2009. Selective inhibition of prostaglandin E2 receptors EP2 and EP4 induces apoptosis of human endometriotic cells through suppression of ERK1/2, AKT, NFkB and b-catenin pathways and activation of intrinsic apoptotic mechanisms. Mol. Endocrinol. 23:1291-1305

Banu, S. K., J. Lee, S. D. Stephen, T. K. Nithy, and J. A. Arosh. 2010. Interferon tau regulates PGF2alpha release from the ovine endometrial epithelial cells via activation of novel JAK/EGFR/ERK/ EGR-1 pathways. Mol. Endocrinol. 24:2315-2330.

Bazer, F. W., and W. W. Thatcher. 1977. Theory of maternal recognition of pregnancy in swine based on estrogen controlled endocrine versus exocrine secretion of prostaglandin F2alpha by the uterine endometrium. Prostaglandins 14:397-400.

Bott, R. C., R. L. Ashley, L. E. Henkes, A. Q. Antoniazzi, J. E. Bruemmer, G. D. Niswender, F. W. Bazer, T. E. Spencer, N. P. Smirnova, R. V. Anthony, and T. R. Hansen. 2010. Uterine vein infusion of interferon tau (IFNT) extends luteal life span in ewes. Biol. Reprod. 82:725-735.

Buchanan, F. G., D. L. Gorden, P. Matta, Q. Shi, L. M. Matrisian, and R. N. DuBois. 2006. Role of beta-arrestin 1 in the metastatic progression of colorectal cancer. Proc. Natl. Acad. Sci. USA 103:1492-1497.

Castellone, M. D., H. Teramoto, B. O. Williams, K. M. Druey, and J. S. Gutkind. 2005. Prostaglandin E2 promotes colon cancer cell growth through a Gs-axin-beta-catenin signaling axis. Science 310:1504-1510.

Cha, Y. I., and R. N. DuBois. 2007. NSAIDs and cancer prevention: Targets downstream of COX-2. Annu. Rev. Med. 58:239-252.

Chan, B. S., J. A. Satriano, M. Pucci, and V. L. Schuster. 1998. Mechanism of prostaglandin E2 transport across the plasma membrane of HeLa cells and Xenopus oocytes expressing the prostaglandin transporter "PGT". J. Biol. Chem. 273:6689-6697.

Charpigny, G., P. Reinaud, J. P. Tamby, C. Creminon, and M. Guillomot. 1997. Cyclooxygenase-2 unlike cyclooxygenase- 1 is highly expressed in ovine embryos during the implantation period. Biol. Reprod. 57:1032-1040.

Chen, Y., J. A. Green, E. Antoniou, A. D. Ealy, N. Mathialagan, A. M. Walker, M. P. Avalle, C. S. Rosenfeld, L. B. Hearne, and R. M. Roberts. 2006. Effect of interferon-tau administration on endometrium of nonpregnant ewes: A comparison with pregnant ewes. Endocrinology 147:2127-2137.

Choi, Y., G. A. Johnson, R. C. Burghardt, L. R. Berghman, M. M. Joyce, K. M. Taylor, M. D. Stewart, F. W. Bazer, and T. E. Spencer. 2001. Interferon regulatory factor-two restricts expression of interferon-stimulated genes to the endometrial stroma and glandular epithelium of the ovine uterus. Biol. Reprod. 65:1038-1049.

Clevers, H. 2006. Colon cancer-Understanding how NSAIDs work. N. Engl. J. Med. 354:761-763.

Coleman, R. A., W. L. Smith, and S. Narumiya. 1994. International Union of Pharmacology classification of prostanoid receptors: Properties, distribution, and structure of the receptors and their subtypes. Pharmacol. Rev. 46:205-229.

Costine, B. A., E. K. Inskeep, K. P. Blemings, J. A. Flores, and M. E. Wilson. 2007. Mechanisms of reduced luteal sensitivity to prostaglandin F2alpha during maternal recognition of pregnancy in ewes. Domest. Anim. Endocrinol. 32:106-121.

Davis, A. J., I. R. Fleet, P. A. Hansford, F. A. Harrison, and F. M. Maule Walker. 1980. Pulmonary metabolism of prostaglandin F2a in the conscious non-pregnant ewe and sow. J. Physiol. 301:86P.

Davis, J. S., and B. R. Rueda. 2002. The corpus luteum: An ovarian structure with maternal instincts and suicidal tendencies. Front. Biosci. 7:1949-1978.

Dorniak, P., F. W. Bazer, and T. E. Spencer. 2011. Prostaglandins regulate conceptus elongation and mediate effects of interferon tau on the ovine uterine endometrium. Biol. Reprod. 84:1119-1127.

Eisinger, A. L., S. M. Prescott, D. A. Jones, and D. M. Stafforini. 2007. The role of cyclooxygenase- 2 and prostaglandins in colon cancer. Prostaglandins Other Lipid Mediat. 82:147-154.

Ellinwood, W. E., T. M. Nett, and G. D. Niswender. 1979. Maintenance of the corpus luteum of early pregnancy in the ewe. II. Prostaglandin secretion by the endometrium in vitro and in vivo. Biol. Reprod. 21:845-856.

Fernandez-Alvarez, A., G. Tur, G. Lopez-Rodas, and M. Casado. 2008. Reciprocal regulation of the human sterol regulatory element binding protein (SREBP)-1a promoter by Sp1 and EGR-1 transcription factors. FEBS Lett. 582:177-184.

Fleming, J. G., T. E. Spencer, S. H. Safe, and F. W. Bazer. 2006. Estrogen regulates transcription of the ovine oxytocin receptor gene through GC-rich SP1 promoter elements. Endocrinology 147:899-911.

Ginther, O. J. 1981. Local versus systemic uteroovarian relationships in farm animals. Acta Vet. Scand. Suppl. 77:103-115. 
Godkin, J. D., F. W. Bazer, and R. M. Roberts. 1984. Ovine trophoblast protein 1, an early secreted blastocyst protein, binds specifically to uterine endometrium and affects protein synthesis. Endocrinology 114:120-130.

Guo, C. M., N. Kasaraneni, K. Sun, and L. Myatt. 2012. Cross talk between PKC and CREB in the induction of COX-2 by PGF2alpha in human amnion fibroblasts. Endocrinology 153:4938-4945.

Guthrie, H. D. 1979. In discussion of luteolysis. Adv. Exp. Med. Biol. 112:621-625.

Henderson, K. M., R. J. Scaramuzzi, and D. T. Baird. 1977. Simultaneous infusion of prostaglandin E2 antagonizes the luteolytic action of prostaglandin F2alpha in vivo. J. Endocrinol. 72:379-383.

Hooper, S. B., W. B. Watkins, and G. D. Thorburn. 1986. Oxytocin, oxytocin-associated neurophysin, and prostaglandin F2 alpha concentrations in the utero-ovarian vein of pregnant and nonpregnant sheep. Endocrinology 119:2590-2597.

Hyland, J. H., J. G. Manns, and W. D. Humphrey. 1982. Prostaglandin production by ovine embryos and endometrium in vitro. J. Reprod. Fertil. 65:299-304.

Imakawa, K., R. V. Anthony, M. Kazemi, K. R. Marotti, H. G. Polites, and R. M. Roberts. 1987. Interferon-like sequence of ovine trophoblast protein secreted by embryonic trophectoderm. Nature 330:377-379.

Inskeep, E. K., W. J. Smutny, R. L. Butcher, and J. E. Pexton. 1975. Effects of intrafollicular injections of prostaglandins in non-pregnant and pregnant ewes. J. Anim. Sci. 41:1098-1104.

Juengel, J. L., H. A. Garverick, A. L. Johnson, R. S. Youngquist, and M. F. Smith. 1993. Apoptosis during luteal regression in cattle. Endocrinology 132:249-254.

Kanai, N., R. Lu, J. A. Satriano, Y. Bao, A. W. Wolkoff, and V. L. Schuster. 1995. Identification and characterization of a prostaglandin transporter. Science 268:866-869.

Kittok, R. J., and J. H. Britt. 1977. Corpus luteum function in ewes given estradiol during the estrous cycle or early pregnancy. J. Anim. Sci. 45:336-341.

Kudo, I., and M. Murakami. 1999. Diverse functional coupling of prostanoid biosynthetic enzymes in various cell types. Adv. Exp. Med. Biol. 469:29-35.

Lacroix, M. C., and G. Kann. 1982. Comparative studies of prostaglandins F2 alpha and E2 in late cyclic and early pregnant sheep: In vitro synthesis by endometrium and conceptus effects of in vivo indomethacin treatment on establishment of pregnancy. Prostaglandins 23:507-526.

Lee, J., S. K. Banu, J. A. McCracken, and J. A. Arosh. 2015. Early pregnancy modulates survival and apoptosis pathways in the corpus luteum in sheep. Reproduction 151:187-201.

Lee, J., S. K. Banu, T. K. Nithy, J. A. Stanley, and J. A. Arosh. 2012a Early pregnancy induced expression of prostaglandin E2 receptors EP2 and EP4 in the ovine endometrium and regulated by interferon tau through multiple cell signaling pathways. Mol. Cell. Endocrinol. 348:211-223.

Lee, J., J. A. McCracken, S. K. Banu, and J. A. Arosh. 2013. Intrauterine PGF2alpha pulses without suppressing endometrial expression of estradiol or oxytocin receptor in ruminants. Biol. Reprod. 89:27.

Lee, J., J. A. McCracken, S. K. Banu, R. Rodriguez, T. K. Nithy, and J. A. Arosh. 2010. Transport of prostaglandin F(2alpha) pulses from the uterus to the ovary at the time of luteolysis in ruminants is regulated by prostaglandin transporter-mediated mechanisms. Endocrinology 151:3326-3335.

Lee, J., J. A. McCracken, J. A. Stanley, T. K. Nithy, S. K. Banu, and J. A. Arosh. 2012b. Intraluteal prostaglandin biosynthesis and signaling are selectively directed towards PGF2alpha during luteolysis but towards PGE2 during the establishment of pregnancy in sheep. Biol. Reprod. 87:97.

Lee, J., J. A. Stanley, J. A. McCracken, S. K. Banu, and J. A. Arosh. 2014. Intrauterine coadministration of ERK1/2 inhibitor U0126 inhibits interferon TAU action in the endometrium and restores luteolytic PGF2alpha pulses in sheep. Biol. Reprod. 91:46.

Lewis, G. S., P. E. Jenkins, R. L. Fogwell, and E. K. Inskeep. 1978. Concentrations of prostaglandins E2 and F2 alpha and their re- lationship to luteal function in early pregnant ewes. J. Anim. Sci. 47:1314-1323.

Magness, R. R., J. M. Huie, G. L. Hoyer, T. P. Huecksteadt, L. P. Reynolds, G. J. Seperich, G. Whysong, and C. W. Weems. 1981. Effect of chronic ipsilateral or contralateral intrauterine infusion of prostaglandin E2 (PGE2) on luteal function of unilaterally ovariectomized ewes. Prostaglandins Med. 6:389-401.

Mann, G. E., G. E. Lamming, R. S. Robinson, and D. C. Wathes. 1999. The regulation of interferon-tau production and uterine hormone receptors during early pregnancy. J. Reprod. Fertil. Suppl. $54: 317-328$.

Manna, P. R., M. T. Dyson, and D. M. Stocco. 2009. Regulation of the steroidogenic acute regulatory protein gene expression: Present and future perspectives. Mol. Hum. Reprod. 15:321-333.

Mapletoft, R. J., M. R. Del Campo, and O. J. Ginther. 1975. Unilateral luteotropic effect of uterine venous effluent of a gravid uterine horn in sheep. Proc. Soc. Exp. Biol. Med. 150:129-133.

Mapletoft, R. J., M. R. Del Campo, and O. J. Ginther. 1976a. Local venoarterial pathway for uterine-induced luteolysis in cows. Proc. Soc. Exp. Biol. Med. 153:289-294.

Mapletoft, R. J., and O. J. Ginther. 1975. Adequacy of main uterine vein and the ovarian artery in the local venoarterial pathway for uterine-induced luteolysis in ewes. Am. J. Vet. Res. 36:957-963.

Mapletoft, R. J., D. R. Lapin, and O. J. Ginther. 1976b. The ovarian artery as the final component of the local luteotropic pathway between a gravid uterine horn and ovary in ewes. Biol. Reprod. $15: 414-421$.

Marcus, G. J. 1981. Prostaglandin formation by the sheep embryo and endometrium as an indication of maternal recognition of pregnancy. Biol. Reprod. 25:56-64.

McCracken, J. A. 2005. Prostaglandins and leukotrienes. Pages 93-111 in Endocrinology: Basic and Clinical Principles. S. A. C. Melmed, P. M., ed. Humana Press, Totowa, NJ.

McCracken, J. A., D. T. Baird, and J. R. Goding. 1971. Factors affecting the secretion of steroids from the transplanted ovary in the sheep. Recent Prog. Horm. Res. 27:537-582., passim.

McCracken, J. A., B. Barcikowski, J. C. Carlson, K. Green, and B. Samuelsson. 1973. The physiological role of prostaglandin F2alpha in corpus luteum regression. Adv. Biosci. 9:599-624.

McCracken, J. A., J. C. Carlson, M. E. Glew, J. R. Goding, D. T Baird, K. Green, and B. Samuelsson. 1972. Prostaglandin F 2 identified as a luteolytic hormone in sheep. Nat. New Biol. 238:129134.

McCracken, J. A., E. E. Custer, and J. C. Lamsa. 1999. Luteolysis: A neuroendocrine-mediated event. Physiol. Rev. 79:263-323.

McCracken, J. A., E. E. Custer, J. C. Lamsa, and A. G. Robinson. 1995. The central oxytocin pulse generator: A pacemaker for luteolysis. Adv. Exp. Med. Biol. 395:133-154.

McCracken, J. A., E. E. Custer, D. T. Schreiber, P. C. Tsang, C. S. Keator, and J. A. Arosh. 2012. A new in vivo model for luteolysis using systemic pulsatile infusions of PGF(2alpha). Prostaglandins Other Lipid Mediat. 97:90-96.

Moor, R. M., M. F. Hay, R. V. Short, and L. E. Rowson. 1970. The corpus luteum of the sheep: Effect of uterine removal during luteal regression. J. Reprod. Fertil. 21:319-326.

Moor, R. M., and L. E. Rowson. 1964. Influence of the embryo and uterus on luteal function in the sheep. Nature 201:522-523.

Moor, R. M., and L. E. Rowson. 1966a. The corpus luteum of the sheep: Effect of the removal of embryos on luteal function. J. Endocrinol. 34:497-502.

Moor, R. M., and L. E. Rowson. 1966b. Local maintenance of the corpus luteum in sheep with embryos transferred to various isolated portions of the uterus. J. Reprod. Fertil. 12:539-550.

Moor, R. M., and L. E. Rowson. 1966c. Local uterine mechanisms affecting luteal function in the sheep. J. Reprod. Fertil. 11:307-310.

Moor, R. M., L. E. Rowson, M. F. Hay, and B. V. Caldwell. 1969. The corpus luteum of the sheep: Effect of the conceptus on luteal function at several stages during pregnancy. J. Endocrinol. 43:301-307.

Nancarrow, C. D., B. M. Evison, and P. J. Connell. 1982. Effect of embryos on luteolysis and termination of early pregnancy in sheep with cloprostenol. Biol. Reprod. 26:263-269. 
Narumiya, S., and G. A. FitzGerald. 2001. Genetic and pharmacological analysis of prostanoid receptor function. J. Clin. Invest. 108:25-30.

Narumiya, S., Y. Sugimoto, and F. Ushikubi. 1999. Prostanoid receptors: Structures, properties, and functions. Physiol. Rev. 79:11931226 .

Niswender, G. D. 2002. Molecular control of luteal secretion of progesterone. Reproduction 123:333-339.

Niswender, G. D., T. L. Davis, R. J. Griffith, R. L. Bogan, K. Monser, R. C. Bott, J. E. Bruemmer, and T. M. Nett. 2007. Judge, jury and executioner: The auto-regulation of luteal function. Soc. Reprod. Fertil. Suppl. 64:191-206.

Niswender, G. D., J. L. Juengel, P. J. Silva, M. K. Rollyson, and E. W. McIntush. 2000. Mechanisms controlling the function and life span of the corpus luteum. Physiol. Rev. 80:1-29.

Nithy, T. K., J. Lee, S. D. Stephen, J. A. Stanley, S. K. Banu, T. E. Spencer, and J. A. Arosh. 2011. Selective inhibition of prostaglandin receptors EP2 and EP4 suppresses growth and development of the ovine conceptus. Biol. Reprod. Suppl. (Abstract).

Oliveira, J. F., L. E. Henkes, R. L. Ashley, S. H. Purcell, N. P. Smirnova, D. N. Veeramachaneni, R. V. Anthony, and T. R. Hansen. 2008. Expression of interferon (IFN)-stimulated genes in extrauterine tissues during early pregnancy in sheep is the consequence of endocrine IFN-tau release from the uterine vein. Endocrinology $149: 1252-1259$.

Pratt, B. R., R. L. Butcher, and E. K. Inskeep. 1977. Antiluteolytic effect of the conceptus and of PGE2 in ewes. J. Anim. Sci. 45:784791.

Pratt, B. R., R. L. Butcher, and E. K. Inskeep. 1979. Effect of continuous intrauterine administration of prostaglandin E2 on life span of corpora lutea of nonpregnant ewes. J. Anim. Sci. 48:1441-1446.

Rawlings, N. C., and J. H. Hyland. 1985. Prostaglandin F and E levels in the conceptus, uterus and plasma during early pregnancy in the ewe. Prostaglandins 29:933-951.

Raychowdhury, R., G. Schafer, J. Fleming, S. Rosewicz, B. Wiedenmann, T. C. Wang, and M. Hocker. 2002. Interaction of early growth response protein 1 (Egr-1), specificity protein 1 (Sp1), and cyclic adenosine $3^{\prime} 5^{\prime}$-monophosphate response element binding protein (CREB) at a proximal response element is critical for gastrin-dependent activation of the chromogranin A promoter. Mol. Endocrinol. 16:2802-2818.

Reid, G., P. Wielinga, N. Zelcer, I. van der Heijden, A. Kuil, M. de Haas, J. Wijnholds, and P. Borst. 2003. The human multidrug resistance protein MRP4 functions as a prostaglandin efflux transporter and is inhibited by nonsteroidal antiinflammatory drugs. Proc. Natl. Acad. Sci. USA 100:9244-9249.

Rexroad, C. E. Jr., and H. D. Guthrie. 1979. Prostaglandin F2 alpha and progesterone release in vitro by ovine luteal tissue during induced luteolysis. Adv. Exp. Med. Biol. 112:639-644.

Reynolds, L. P., D. A. Robertson, and S. P. Ford. 1983. Effects of intrauterine infusion of oestradiol-17 beta and prostaglandin E-2 on luteal function in non-pregnant heifers. J. Reprod. Fertil. 69:703709

Reynolds, L. P., J. Stigler, G. L. Hoyer, R. R. Magness, J. M. Huie, T. P. Huecksteadt, G. L. Whysong, H. R. Behrman, and C. W. Weems. 1981. Effect of PGE1 on PGF2 alpha-induced luteolysis in nonbred ewes. Prostaglandins 21:957-972.

Robinson, R. S., A. J. Hammond, D. C. Wathes, M. G. Hunter, and G. E. Mann. 2008. Corpus luteum-endometrium-embryo interactions in the dairy cow: Underlying mechanisms and clinical relevance. Reprod. Domest. Anim. 43(Suppl 2):104-112.

Romero, J. J., A. Q. Antoniazzi, T. M. Nett, R. L. Ashley, B. T. Webb, N. P. Smirnova, R. C. Bott, J. E. Bruemmer, F. W. Bazer, R. V. Anthony, and T. R. Hansen. 2015. Temporal release, paracrine and endocrine actions of ovine conceptus-derived interferontau during early pregnancy. Biol. Reprod. 93:146.

Rosenfeld, C. S., C. S. Han, A. P. Alexenko, T. E. Spencer, and R. M. Roberts. 2002. Expression of interferon receptor subunits, IFNAR1 and IFNAR2, in the ovine uterus. Biol. Reprod. 67:847-853.
Rowson, L. E., and R. M. Moor. 1967. The influence of embryonic tissue homogenate infused into the uterus, on the life-span of the corpus luteum in the sheep. J. Reprod. Fertil. 13:511-516.

Sales, K. J., S. C. Boddy, A. R. Williams, R. A. Anderson, and H. N. Jabbour. 2007. F-prostanoid receptor regulation of fibroblast growth factor 2 signaling in endometrial adenocarcinoma cells. Endocrinology 148:3635-3644.

Sales, K. J., T. List, S. C. Boddy, A. R. Williams, R. A. Anderson, Z. Naor, and H. N. Jabbour. 2005. A novel angiogenic role for prostaglandin F2alpha-FP receptor interaction in human endometrial adenocarcinomas. Cancer Res. 65:7707-7716.

Sawyer, H. R., K. D. Niswender, T. D. Braden, and G. D. Niswender. 1990. Nuclear changes in ovine luteal cells in response to PGF2 alpha. Domest. Anim. Endocrinol. 7:229-237.

Schuster, V. L. 1998. Molecular mechanisms of prostaglandin transport. Annu. Rev. Physiol. 60:221-242.

Schuster, V. L. 2002. Prostaglandin transport. Prostaglandins Other Lipid Mediat. 68-69:633-647.

Silva, P. J., J. L. Juengel, M. K. Rollyson, and G. D. Niswender. 2000. Prostaglandin metabolism in the ovine corpus luteum: Catabolism of prostaglandin $\mathrm{F}$ (2alpha) (PGF (2alpha)) coincides with resistance of the corpus luteum to PGF(2alpha). Biol. Reprod. 63:1229-1236.

Silvia, W. J., and G. D. Niswender. 1984. Maintenance of the corpus luteum of early pregnancy in the ewe. III. Differences between pregnant and nonpregnant ewes in luteal responsiveness to prostaglandin F2 alpha. J. Anim. Sci. 59:746-753.

Silvia, W. J., and G. D. Niswender. 1986. Maintenance of the corpus luteum of early pregnancy in the ewe. IV. Changes in luteal sensitivity to prostaglandin F2 alpha throughout early pregnancy. J. Anim. Sci. 63:1201-1207.

Silvia, W. J., J. S. Ottobre, and E. K. Inskeep. 1984. Concentrations of prostaglandins E2, F2 alpha and 6-keto-prostaglandin F1 alpha in the utero-ovarian venous plasma of nonpregnant and early pregnant ewes. Biol. Reprod. 30:936-944.

Smith, W. L., and D. L. Dewitt. 1996. Prostaglandin endoperoxide H synthases-1 and -2. Adv. Immunol. 62:167-215.

Smith, W. L., and I. Song. 2002. The enzymology of prostaglandin endoperoxide $\mathrm{H}$ synthases- 1 and -2 . Prostaglandins Other Lipid Mediat. 68-69:115-128.

Song, G., T. E. Spencer, and F. W. Bazer. 2006. Progesterone and interferon-tau regulate cystatin $\mathrm{C}$ in the endometrium. Endocrinology 147:3478-3483.

Spencer, T. E., W. C. Becker, P. George, M. A. Mirando, T. F. Ogle, and F. W. Bazer. 1995a. Ovine interferon-tau inhibits estrogen receptor up-regulation and estrogen-induced luteolysis in cyclic ewes. Endocrinology 136:4932-4944.

Spencer, T. E., W. C. Becker, P. George, M. A. Mirando, T. F. Ogle, and F. W. Bazer. 1995b. Ovine interferon-tau regulates expression of endometrial receptors for estrogen and oxytocin but not progesterone. Biol. Reprod. 53:732-745.

Spencer, T. E., R. C. Burghardt, G. A. Johnson, and F. W. Bazer. 2004. Conceptus signals for establishment and maintenance of pregnancy. Anim. Reprod. Sci. 82-83:537-550.

Spencer, T. E., N. Forde, P. Dorniak, T. R. Hansen, J. J. Romero, and P. Lonergan. 2013. Conceptus-derived prostaglandins regulate gene expression in the endometrium prior to pregnancy recognition in ruminants. Reproduction 146:377-387.

Spencer, T. E., N. H. Ing, T. L. Ott, J. S. Mayes, W. C. Becker, G. H. Watson, M. A. Mirando, and F. W. Brazer. 1995c. Intrauterine injection of ovine interferon-tau alters oestrogen receptor and oxytocin receptor expression in the endometrium of cyclic ewes. J. Mol. Endocrinol. 15:203-220.

Spencer, T. E., G. A. Johnson, F. W. Bazer, and R. C. Burghardt. 2007. Fetal-maternal interactions during the establishment of pregnancy in ruminants. Soc. Reprod. Fertil. Suppl. 64:379-396.

Spencer, T. E., T. L. Ott, and F. W. Bazer. 1998. Expression of interferon regulatory factors one and two in the ovine endometrium: Effects of pregnancy and ovine interferon tau. Biol. Reprod. 58:1154-1162. 
Spencer, T. E., A. G. Stagg, T. L. Ott, G. A. Johnson, W. S. Ramsey, and F. W. Bazer. 1999. Differential effects of intrauterine and subcutaneous administration of recombinant ovine interferon tau on the endometrium of cyclic ewes. Biol. Reprod. 61:464-470.

Stewart, M. D., G. A. Johnson, C. A. Vyhlidal, R. C. Burghardt, S. H. Safe, L. Y. Yu-Lee, F. W. Bazer, and T. E. Spencer. 2001. Interferon-tau activates multiple signal transducer and activator of transcription proteins and has complex effects on interferonresponsive gene transcription in ovine endometrial epithelial cells. Endocrinology 142:98-107.

Sugino, N., and K. Okuda. 2007. Species-related differences in the mechanism of apoptosis during structural luteolysis. J. Reprod. Dev. 53:977-986.

Tai, H. H., C. M. Ensor, M. Tong, H. Zhou, and F. Yan. 2002. Prostaglandin catabolizing enzymes. Prostaglandins Other Lipid Mediat. 68-69:483-493.

Thorén, S., and P. J. Jakobsson. 2000. Coordinate up- and downregulation of glutathione-dependent prostaglandin E synthase and cyclooxygenase-2 in A549 cells. Inhibition by NS-398 and leukotriene C4. Eur. J. Biochem. 267:6428-6434.

Thorén, S., R. Weinander, S. Saha, C. Jegerschold, P. L. Pettersson, B. Samuelsson, H. Hebert, M. Hamberg, R. Morgenstern, and P. J. Jakobsson. 2003. Human microsomal prostaglandin E synthase-1: Purification, functional characterization, and projection structure determination. J. Biol. Chem. 278:22199-22209.

Tsai, S. J., and M. C. Wiltbank. 1997. Prostaglandin F2alpha induces expression of prostaglandin $\mathrm{G} / \mathrm{H}$ synthase-2 in the ovine corpus luteum: A potential positive feedback loop during luteolysis. Biol. Reprod. 57:1016-1022.

Tsai, S. J., and M. C. Wiltbank. 1998. Prostaglandin F2alpha regulates distinct physiological changes in early and mid-cycle bovine corpora lutea. Biol. Reprod. 58:346-352.

Vincent, D. L., and E. K. Inskeep. 1986. Role of progesterone in regulating uteroovarian venous concentrations of PGF2 alpha and PGE2 during the estrous cycle and early pregnancy in ewes. Prostaglandins 31:715-733.

Vincent, D. L., S. Meredith, and E. K. Inskeep. 1986. Advancement of uterine secretion of prostaglandin E2 by treatment with pro- gesterone and transfer of asynchronous embryos. Endocrinology 119:527-529.

Wang, D., and R. N. Dubois. 2006. Prostaglandins and cancer. Gut $55: 115-122$.

Wang, S. Z., and R. M. Roberts. 2004. Interaction of stress-activated protein kinase-interacting protein-1 with the interferon receptor subunit IFNAR2 in uterine endometrium. Endocrinology 145:5820-5831.

Weems, C. W., Y. S. Weems, and R. D. Randel. 2006. Prostaglandin and reproduction in female farm animals. Vet. J. 171:206-228.

Weems, Y. S., P. J. Bridges, M. Jeoung, J. A. Arreguin-Arevalo, T. M. Nett, R. C. Vann, S. P. Ford, A. W. Lewis, D. A. Neuendorff, T. H. Welsh Jr., R. D. Randel, and C. W. Weems. 2012. In vivo intra-luteal implants of prostaglandin (PG) E1 or E2 (PGE1, PGE2) prevent luteolysis in cows. II: mRNA for PGF2alpha, EP1, EP2, EP3 (A-D), EP3A, EP3B, EP3C, EP3D, and EP4 prostanoid receptors in luteal tissue. Prostaglandins Other Lipid Mediat. 97:60-65.

Wiepz, G. J., M. C. Wiltbank, T. M. Nett, G. D. Niswender, and H. R. Sawyer. 1992. Receptors for prostaglandins F2 alpha and E2 in ovine corpora lutea during maternal recognition of pregnancy. Biol. Reprod. 47:984-991.

Wiltbank, M. C., C. J. Belfiore, and G. D. Niswender. 1993. Steroidogenic enzyme activity after acute activation of protein kinase (PK) A and PKC in ovine small and large luteal cells. Mol. Cell. Endocrinol. 97:1-7.

Wiltbank, M. C., T. F. Shiao, D. R. Bergfelt, and O. J. Ginther. 1995. Prostaglandin F2 alpha receptors in the early bovine corpus luteum. Biol. Reprod. 52:74-78.

Zarco, L., G. H. Stabenfeldt, S. Basu, G. E. Bradford, and H. Kindahl. 1988. Modification of prostaglandin F-2 alpha synthesis and release in the ewe during the initial establishment of pregnancy. J. Reprod. Fertil. 83:527-536.

Zheng, J., P. M. Fricke, L. P. Reynolds, and D. A. Redmer. 1994. Evaluation of growth, cell proliferation, and cell death in bovine corpora lutea throughout the estrous cycle. Biol. Reprod. 51:623-632. 